\title{
Stability Analyses and Cable Bolt Support Design for A Deep Large-Span Stope at the Hongtoushan Mine, China
}

\author{
Xingdong Zhao *, Huaibin $\mathrm{Li}{ }^{\circledR}$, Shujing Zhang and Xiaoming Yang \\ Geomechanics Research Center, Northeastern University, Shenyang 110819, China; \\ lihuaibin1987@163.com (H.L.); shujing16@126.com (S.Z.); yangxiaoming@mail.neu.edu.cn (X.Y.) \\ * Correspondence: zhaoxingdong@mail.neu.edu.cn
}

Received: 23 September 2019; Accepted: 31 October 2019; Published: 3 November 2019

check for updates

\begin{abstract}
This study presents stability analyses and a cable bolt support design for a typical deep large-span stope (1-1\# stope) at the Hongtoushan mine in China, using an integrated empirical and numerical method. Detailed field work including quantification of joint distribution and surface quality, along with laboratory test on intact rock samples, were performed to obtain the geotechnical properties of rock masses. The rock mass of the 1-1\# stope was characterized by rock mass rating (RMR), rock mass quality (Q), and geological strength index (GSI), and then the modulus, peak strength, cohesive strength, and internal friction angle of the rock mass were estimated. The stability of the stope was then evaluated by empirical (RMR, stability graph) and numerical approaches (limit equilibrium analyses with UNWEDGE and stress-strain analyses with FLAC3D), considering of the effects of rock mass quality, induced stress, and large-span. A cable bolt support system obtained from the empirical method, was then further analyzed using the FLAC3D and UNWEDGE codes. The results show that the maximum plastic zone thickness and vertical displacement at the stope roof decrease significantly and the safety factor of the unstable wedge block increases significantly after installing the cable bolt support systems recommended by the empirical method. Therefore, it is suggested that an integrated empirical and numerical method is used to obtain quantitative stability assessment and optimum cable bolt support design for deep large-span stope roofs.
\end{abstract}

Keywords: rock mass classification; stability graph; numerical modeling; stope stability; cable bolt support design; deep large-span stope

\section{Introduction}

Stope roof stability is an essential prerequisite for safe working conditions in overhand cut-and-fill mining. Non-anticipated rock collapses and falls from the stope roof are the primary threat to the safety of underground workers and economic extraction of ore bodies. Such accidents account for approximately $40 \%$ of all injuries and fatalities in underground base metal mines in China [1]. The overhand cut-and-fill mining method has been extensively used in underground base metal mines worldwide, with typical stope dimensions of about $20-35 \mathrm{~m}$ in width and $50-80 \mathrm{~m}$ long in strike, accommodating large mechanized equipment [2]. In general, roof instabilities observed in the field can be related to ground falls owing to excessive stresses or unfavorable geological structures.

Stope stability is significantly affected by geology, stress conditions, mining methods, opening dimensions, support technology, and other factors. Numerous studies have addressed the stability analyses of stopes and drifts using empirical, numerical, and analytical methods, as well as in-situ tests and monitoring methods. For example, the pioneering work of Mathews et al. [3] empirically predicted the stable excavation size for mines at depths below 1000 meters in Canadian hard rock 
using a stability graph. The Mathews method was later modified by Potvin [4], which led to the well-known Mathews-Potvin method. Such empirical methods have been intensively reviewed and modified, resulting in several variants that can be applied to many other conditions [5-9]. Swart and Handley [10] designed a stable range of stopes for shallow mining operations using an integrated method included a stability graph, elastic beam theory, and numerical modeling. Sunwoo et al. [11] predicted the stability of wide underground mine openings using the stability graph. Jordá et al. [12] analyzed the stability of shallow limestone caves at a maximum depth of $55 \mathrm{~m}$ using the stability graph method. Lang [13] developed a critical span curve to evaluate back stability in cut-and-fill mines, which was later modified by Wang et al. [14] and Ouchi et al. [15]. Idris et al. [16] studied the effects of rock mass property variability on open stope stability using finite element methods (FEM). Li et al. [17,18] analyzed the dynamic disasters of deep mining using the analytical and numerical modeling methods. Yang et al. [19] analyzed the stability of a shallow large-scale stope using stage subsequent filling mining methods in the Sijiaying iron mine in China using physical and numerical modeling methods. Heidarzadeh et al. [20] evaluated the effect of geometrical parameters on the probability of stope failure in the open stoping method using numerical modeling. Grenon and Hadjigeorgiou [21] used 3D joint network models and a limit equilibrium analysis to investigate the stability of all potential wedges at the back of a stope. Gao et al. [22] studied the effect of a dip angle in mining direction on drum loading performance used discrete element method (DEM). Su [23] adopted nonlinear programming, a genetic algorithm, and a neural network to optimize the stope structure. Fuzzy mathematics and block theory are useful to analyze stope stability [24,25]. Many other studies have explored stope stability using instrumentation measurements [26-31].

Cable bolts can provide increased stability for various openings in underground mines. The cable bolting patterns for the required stope roof control plans are usually based on past practices. Empirical analyses provide a useful tool for mining engineers to design underground openings and supports [5]. The rock mass rating (RMR) [32] and rock mass quality (Q) [33] are widely used to determine tunneling support requirements. In particular, tunnel support guidelines based on RMR were originally published in the form of a table [32] that provided recommendations for a tunnel span/diameter of 10 meters. Most guidelines were designed for rockbolting and can be used to select spacings for face support to supplement cable bolts in a fractured rock mass. A design graph for cable bolt density proposed by Potvin [4] relates cable bolt density to a relative block size factor. This graph was developed from a database made of cable-bolted stope backs and was not intended for the design of hanging walls. Fuller [34] described a cable design method for a point anchor cable pattern based on beam theory that is commonly applied to layered rock masses. Barton [35] presented a tabulated series of detailed support recommendations based on different combinations of rock quality, $\mathrm{N}^{\prime}$. Hutchinson and Diederichs [36] proposed the cable bolt design graph based on empirical methods and mechanistic assumptions. Hutchinson and Falmagne [37] optimized cable bolting patterns in cut-and-fill stopes (between the $-70 \mathrm{ft}$ and $-170 \mathrm{ft}$ levels) at the Chikla mine using observational, empirical, and numerical modeling methods. Liu et al. [38] applied the empirical rock mass classification and numerical modeling to provide a reliance support design for a shallow large-scale underground water-sealed oil storage cavern. Skrzypkowski et al. $[39,40]$ studied the stress-strain characteristic of the long point resin and expansion cable bolt. The literature provides valuable resources for stability analyses and support design of stope. However, systematic studies involving stability analysis and support design of deep large-span stopes are seldom reported. A thorough analysis of stope stability and determination of a reasonable cable bolt support system are crucial to ensure that mining operations are carried out economically, safely, and successfully. Many factors that influence the stability of deep large-span stopes are difficult to monitor during mining. There is therefore no single method for stability analysis and support design. The geomechanics classification or RMR [41] and stability graph $[4,5,36,42,43]$ are the most widely used empirical methods in consideration of the rock mass quality, induced stress, and large-span effects. However, these empirical methods cannot adequately provide the stress, displacement, plastic zone distribution, or safety factor information for deep large-span stopes. 
In order to solve the issues mentioned above, this paper summarizes and evaluates the results of stope and rock mass characteristics. An integrated empirical and numerical method to assess potentially unstable stope roof conditions is discussed, and the numerical analysis of support systems obtained from the empirical method is used to evaluate support systems stability for a deep large-span stope. After support installation, the maximum plastic zone thickness and vertical displacement at the stope roof decrease significantly and the safety factor of the unstable wedge block increases significantly, and no sign of rock falls.

\section{Site Description}

\subsection{Geological Setting}

The Hongtoushan mine was developed in 1958 and first produced in 1965. It is located in northeastern China, approximately $65 \mathrm{~km}$ east of Fushun city (Figure 1). The Hongtoushan mine lies in the hanging wall of the Hunhe fault zone. The ore reserve is one of the largest discovered deposits in China. The production capacity of the Hongtoushan mine is around 0.65 million tonnes of ore, recovering approximately 8000 tonnes of refined $\mathrm{Cu}, 10,000$ tonnes of $\mathrm{Zn}$, and $300 \mathrm{~kg}$ of $\mathrm{Au}$. It is the deepest base metal mine in China, reaching a depth of $1600 \mathrm{~m}$.

The Hongtoushan mining field contains a number of copper, zinc, and gold ore bodies in a mineralized belt that is $0.55-0.6 \mathrm{~km}$ long and up to $10-30 \mathrm{~m}$ wide. The Hongtoushan copper-zinc ore bodies are a volcanic-associated massive sulfide deposit that occurs within the steeply dipping $45^{\circ}-80^{\circ}$ SE trending $75^{\circ}-85^{\circ}$ E. Occasional tip steeping and overturning is evident [44].
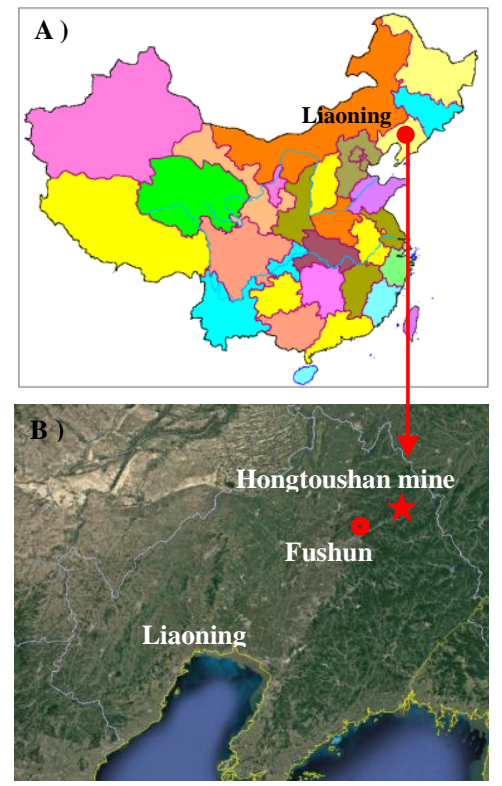

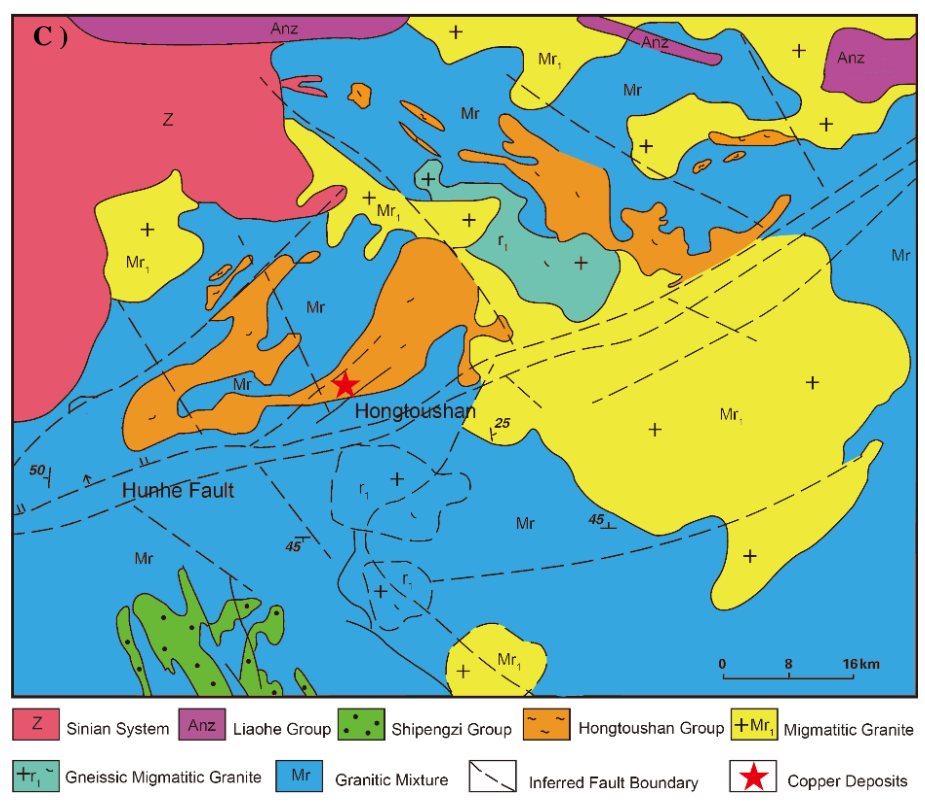

Figure 1. Location and regional geology of the Hongtoushan mine.

The bedding dips steeply at approximate $65^{\circ}-85^{\circ}$ to the northeast and extends downward from the surface $(+430 \mathrm{~m})$ to below $1600 \mathrm{~m}(-1170 \mathrm{~m})$, as shown in Figure 2. The fold axes generally plunge at $75^{\circ}$ in the NS direction. The deposit consists of biotite plagioclase gneiss (hanging wall, $\mathrm{H} / \mathrm{W}$ ), amphibole plagiogneiss (footwall, F/W), and chalcopyrite with pyrite and sphalerite (ore body). As illustrated in Figure 2, $\mathrm{F}_{8}$ is the outstanding fault that affects the stability of the ore bodies that strikes NS and dips at about $75^{\circ}$ eastward. Some small-scale diabase dykes crosscut the country rocks and ore body. These dykes are generally $50 \mathrm{~m}$ wide, strike NS, and dip steeply E. The 1-1\# stope is located at $-767 \mathrm{~m}$ level. 


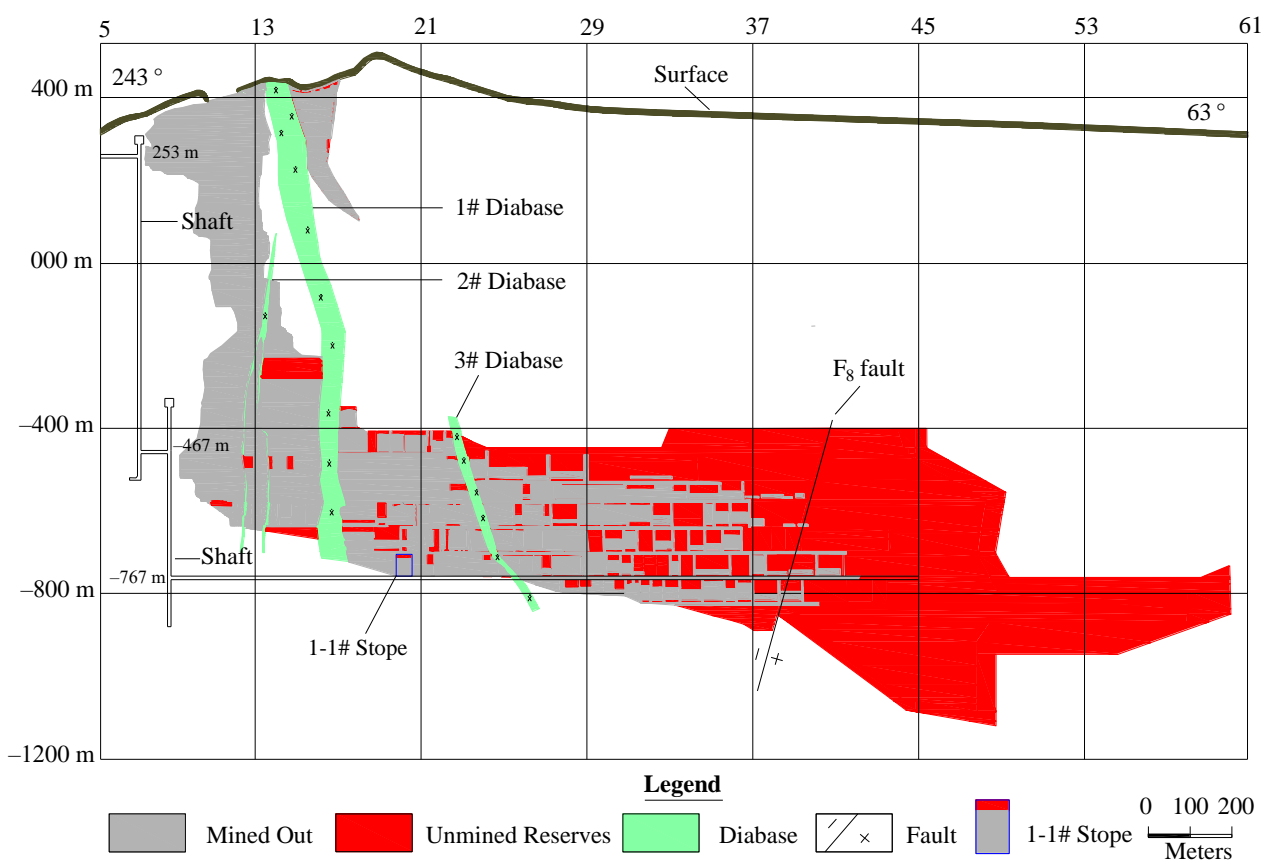

Figure 2. Longitudinal section and major geological structures of the Hongtoushan mine.

\subsection{Mining Methods}

Mining methods used at the Hongtoushan mine include the overhand cut-and-fill mining $(75 \%)$, sub-level stoping with total tailings fill (15\%), and shrinkage stoping (10\%). The overhand cut-and-fill mining method with a pillar was employed at the 1-1\# stope. The stope dimensions are $36 \mathrm{~m}$ high, $20 \mathrm{~m}$ wide, and $50 \mathrm{~m}$ long in the strike, with a $5 \times 5 \mathrm{~m}$ pillar. Parallel blast hole rings were fired in a $3 \mathrm{~m}$ extracting height along a horizontal layer with multiple ring sequences. The stope was filled after every layer of mining. A typical mining arrangement of the 1-1\# stope is shown in Figure 3. Roof falls occurred in a variety of circumstances, which interrupted normal operations.

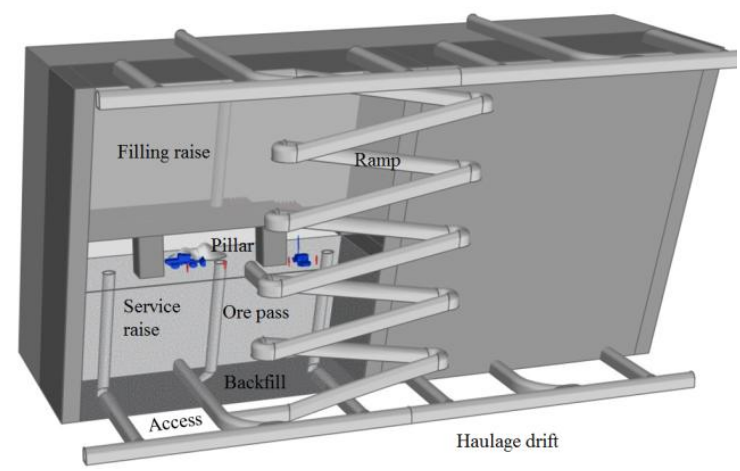

Figure 3. Overhand cut-and-fill mining with pillar in the 1-1\# stope.

\subsection{Stress Conditions}

In-situ stress was estimated using conventional Commonwealth Scientific and Industrial Research Organization (CSIRO) hollow inclusion (HI cell) methodology and the obtained regression equations for predicting geostresses at various depths are as follows [45]:

$$
\left\{\begin{array}{l}
\sigma_{h, \max }=0.0273 H-0.5071 \\
\sigma_{h, \min }=0.0235 H-3.7780 \\
\sigma_{v}=0.0316 H-5.6280
\end{array},\right.
$$


where $\sigma_{\mathrm{h}, \max }, \sigma_{\mathrm{h}, \min }$, and $\sigma_{\mathrm{v}}(\mathrm{MPa})$ are the maximum horizontal principal, minimum horizontal principal, and vertical principal stresses respectively, and $\mathrm{H}$ is the depth $(\mathrm{m})$. According to Equation (1), the maximum horizontal principal stress $\sigma_{\mathrm{h} \text {,max }}$ at $-767 \mathrm{~m}$ (1197 $\mathrm{m}$ depth) reaches $32.2 \mathrm{MPa}$ with a direction of NW, the minor horizontal principal stress $\sigma_{\mathrm{h}, \min }$ is $24.4 \mathrm{MPa}$ in the $167^{\circ} / 60^{\circ}$ plane, and the vertical principal stress $\sigma_{\mathrm{v}}$ is $32.2 \mathrm{MPa}$.

\subsection{Field Survey of Roof Instability}

All 13 different underground stopes at the Hongtoushan mine visited during the course of this study had experienced certain forms of roof instability. Wedge failure and small-scale roof falls were observed, which typically consist of one or more rock fragments of $0.3-1.5 \mathrm{~m}$ in length; larger roof falls typically consist of one or more rock fragments that are 1.5-5 $\mathrm{m}$ in length and can extend over the full length of a stope. Small-scale rock falls had affected about $35 \%$ of the total evaluated area, and large-scale rock falls had affected about $15 \%$. In the remaining areas, the roof was stable with no sign of current or past instability. The cause of the instabilities present in the roof falls was categorized into rock strength, jointing and other geological structures, stope dimensions, and roof performance. The geological structure, large-span roof, and induced stress can result in the collapse of the unsupported roof. Stope support was required to rehabilitate large roof falls. The long grouting cable bolt support was used in the Hongtoushan mine.

\section{Field and Laboratory Studies}

Field and laboratory studies included field observation, discontinuity surveying, and laboratory testing. The study region for the field investigation is the 1-1\# stope at the $-767 \mathrm{~m}$ level, and a detailed engineering geological investigation was carried out at selected $\mathrm{H} / \mathrm{W}$, ore bodies, and $\mathrm{F} / \mathrm{W}$ according to variations of the rock mass (Figure 4). A total of 305 discontinuous measurements were taken from the stope surface exposures by the scanlines method. Figure 5 shows the identification of the field discontinuity sets of $\mathrm{H} / \mathrm{W}$, ore bodies, and F/W in the 1-1\# stope. The statistical data of discontinuity parameters obtained from the 1-1\# stopes are given in Table 1.

Table 1. Statistical results of discontinuity parameters in the 1-1\# stope.

\begin{tabular}{cccccccc}
\hline Site & Length/m & Numbers & $\begin{array}{c}\text { Joint } \\
\text { Set }\end{array}$ & Dip/ & $\begin{array}{c}\text { Dip } \\
\text { Direction }\end{array}$ & Spacing/m & RQD/\% \\
\hline $\begin{array}{c}\text { Biotite plagioclase } \\
\text { gneiss (H/W) }\end{array}$ & \multirow{2}{*}{18.32} & 102 & 2 & $60^{\circ}-80^{\circ}$ & $220^{\circ}-260^{\circ}$ & 0.42 & 43 \\
\hline $\begin{array}{c}\text { Chalcopyrite with } \\
\text { pyrite and sphalerite }\end{array}$ & 22.76 & 106 & 2 & $45^{\circ}-85^{\circ}$ & $160^{\circ}-200^{\circ}$ & 0.38 & 55 \\
(Ore Body) & & & 3 & & $310^{\circ}-360^{\circ}$ & 0.48 & \\
\hline $\begin{array}{c}\text { Amphibole } \\
\text { plagiogneiss (F/W) }\end{array}$ & 28.31 & 97 & 2 & $60^{\circ}-80^{\circ}$ & $210^{\circ}-250^{\circ}$ & 0.55 & 68 \\
\hline
\end{tabular}




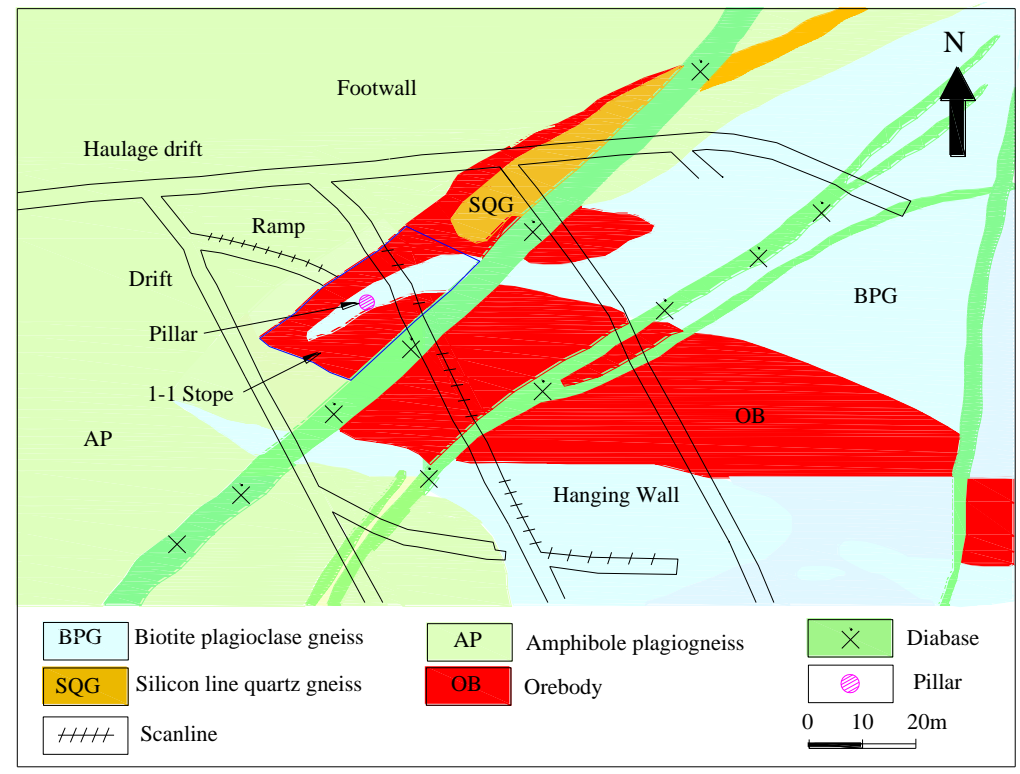

Figure 4. Plane view of engineering geological conditions at the 1-1\# stope.

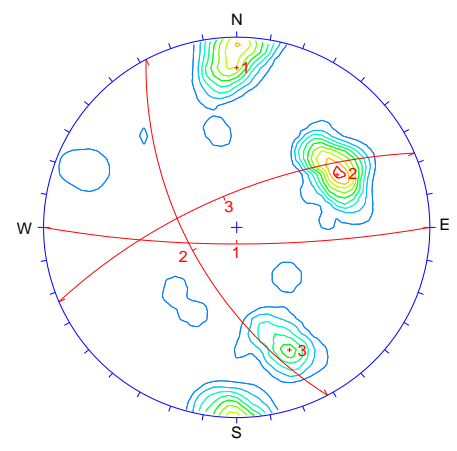

(a) $\mathrm{H} / \mathrm{W}$

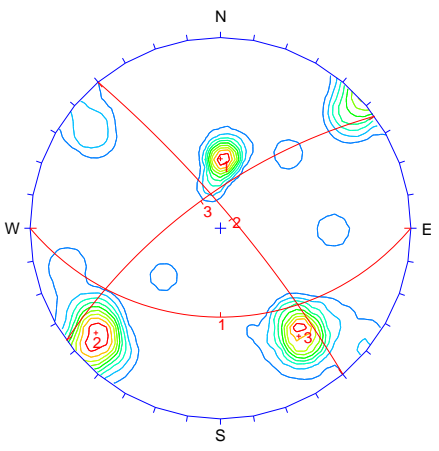

(b) Ore body

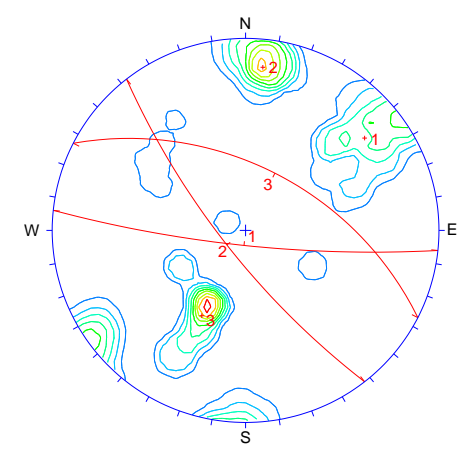

(c) $\mathrm{F} / \mathrm{W}$

Figure 5. Stereographic projection of joint sets in the (a) hanging wall $(\mathrm{H} / \mathrm{W})$; (b) ore body; and (c) footwall $(\mathrm{F} / \mathrm{W})$.

The lithology of the 1-1\# stope is biotite plagioclase gneiss $(\mathrm{H} / \mathrm{W})$, amphibole plagiogneiss (F/W), and chalcopyrite with pyrite and sphalerite (ore body). The backfill is composed of tailings and cement in a ratio of 8:1. The physical and mechanical properties of the rocks were determined from laboratory testing on intact rock samples following recommended methods of the International Society for Rock Mechanics (ISRM) [46]. The test results are listed in Table 2, which also presents the mechanical properties of the backfill.

Table 2. Physical and mechanical properties of intact rock and backfill.

\begin{tabular}{|c|c|c|c|c|c|}
\hline \multirow[b]{2}{*}{ Parameters } & \multirow[b]{2}{*}{ Unit } & \multicolumn{3}{|c|}{ Rock Types } & \multirow[b]{2}{*}{ Backfill } \\
\hline & & $\begin{array}{c}\text { Biotite } \\
\text { Plagioclase } \\
\text { Gneiss (H/W) }\end{array}$ & $\begin{array}{c}\text { Hornblende } \\
\text { Plagioclase } \\
\text { Gneiss (F/W) }\end{array}$ & $\begin{array}{c}\text { Chalcopyrite } \\
\text { (Orebody) }\end{array}$ & \\
\hline Young's modulus/E & GPa & 50.60 & 51.00 & 55.20 & 1.50 \\
\hline Poisson's ratio/v & & 0.21 & 0.23 & 0.24 & 0.20 \\
\hline Density/ $\rho$ & $\mathrm{kg} / \mathrm{m}^{3}$ & 2714 & 2724 & 4224 & 2251 \\
\hline Tensile strength $\sigma_{t}$ & $\mathrm{MPa}$ & 6.77 & 7.49 & 7.23 & 0.53 \\
\hline Cohesion/c & $\mathrm{MPa}$ & 16.30 & 22.80 & 19.30 & 0.51 \\
\hline Internal friction angle $/ \phi$ & $\circ$ & 48.30 & 49.20 & 50.10 & 34.30 \\
\hline Uniaxial compression strength & $\mathrm{MPa}$ & 112.30 & 132.80 & 105.50 & 2.51 \\
\hline
\end{tabular}




\section{Rock Mass Classification Systems}

Typical rock mass classification methods, such as RMR, Q, and geological strength index (GSI), are employed to assess the quality of rock masses, determine rock mass properties, analyze the stope stability, and also provide preliminary support design. For deep large-span stope stability and support design, the most widely used rock mass classification systems (RMR) and stability graph were applied for the 1-1\# stope at the $-767 \mathrm{~m}$ level.

\subsection{RMR System}

The original RMR classification system was proposed and developed by Bieniawski on the basis of shallow tunnels in sedimentary rocks [47]. It was subsequently modified several times and the latest version of RMR ratings remains widely used [32]. The $\mathrm{RMR}_{89}$ system is described using six parameters: uniaxial compressive strength (UCS) of the intact rock, rock quality designation (RQD), joint spacing, joint condition, joint orientation, and ground water conditions. The six input parameters were summed to yield RMR rating results. The rock mass was sorted into five classes on the basis of the RMR rating: very good (100-81), good (80-61), fair (60-41), poor (4-21), and very poor $(<20)$. The basic RMR system has been modified for specific applications, including mining applications [48,49].

The rock masses of the 1-1\# stope at -767 m were classified according to the 1989 version of RMR. The results are listed in Table 3.

Table 3. Evaluation results using the rock mass rating (RMR) system.

\begin{tabular}{|c|c|c|c|}
\hline Parameters/Rating & $\begin{array}{l}\text { Biotite Plagioclase } \\
\text { Gneiss (H/W) }\end{array}$ & $\begin{array}{l}\text { Chalcopyrite with Pyrite } \\
\text { and Sphalerite (Oredody) }\end{array}$ & $\begin{array}{c}\text { Amphibole } \\
\text { Plagiogneiss (F/W) }\end{array}$ \\
\hline UCS (MPa) & 112.3 & 105.5 & 132.8 \\
\hline Rating & 12 & 12 & 12 \\
\hline RQD (\%) & 43 & 55 & 68 \\
\hline Rating & 8 & 13 & 13 \\
\hline Spacing (m) & $0.21-0.42$ & $0.31-0.48$ & $0.45-0.75$ \\
\hline Rating & 10 & 10 & 15 \\
\hline Joint conditions & $\begin{array}{l}\text { Wall is slightly } \\
\text { weathered, surfaces are } \\
\text { rough and apertures } \\
\text { filled by silty clay } \\
(0.5-2.0 \mathrm{~mm})\end{array}$ & $\begin{array}{l}\text { Wall is slightly weathered, } \\
\text { surfaces are rough and } \\
\text { apertures contain calcite and } \\
\text { chlorite filling materials } \\
\text { (about } 1 \mathrm{~mm} \text { ) }\end{array}$ & $\begin{array}{l}\text { Surfaces are smooth } \\
\text { and apertures contain } \\
\text { calcite and chlorite } \\
\text { filling materials } \\
\quad(0.3-3 \mathrm{~mm})\end{array}$ \\
\hline Rating & 15 & 15 & 12 \\
\hline Groundwater conditions & Damp & Damp & Damp \\
\hline Rating & 10 & 10 & 10 \\
\hline Orientation rating & -5 & -5 & -2 \\
\hline Total rating & 50 & 55 & 60 \\
\hline Grade & III & III & III \\
\hline Rock mass quality & Fair & Fair & Fair \\
\hline
\end{tabular}

\subsection{Q System}

The Q-system was developed in the Norwegian Geotechnical Institute (NGI) by Barton et al. [50], and is based on over 200 case histories of tunnels and underground caverns. The Q-system has been updated several times and is now based on 1260 case records [51]. The Q-system employs six parameters: RQD [52], joint set number $\left(\mathrm{J}_{\mathrm{n}}\right)$, joint roughness $(\mathrm{Jr})$, joint alteration $\left(\mathrm{J}_{\mathrm{a}}\right)$, joint water reduction factor $\left(\mathrm{J}_{\mathrm{w}}\right)$, and stress reduction factor $(\mathrm{SRF})$. The $\mathrm{Q}$ rating is derived from the following expression by combining these six parameters:

$$
Q=\left(\frac{R Q D}{J_{n}}\right)\left(\frac{J_{r}}{J_{a}}\right)\left(\frac{J_{w}}{S R F}\right)
$$


The $\mathrm{Q}$ index value can be described by three proportions, as shown in Equation (2): RQD/Jn represents the block size, $\mathrm{J}_{\mathrm{r}} / \mathrm{J}_{\mathrm{a}}$ the inter-block frictional shear strength, and $\mathrm{J}_{\mathrm{w}} / \mathrm{SRF}$ the active stress.

The modified tunneling quality index, $\mathrm{Q}^{\prime}$, calculated in the same way as the standard $\mathrm{Q}$ rock mass classification, except that the stress reduction SRF is set to 1.0. The system has not been applied to conditions with significant groundwater, so the joint water reduction factor $J_{w}$ in Equation (2) is commonly assumed to be 1.0 by Potvin [4]:

$$
Q^{\prime}=\left(\frac{R Q D}{J_{n}}\right)\left(\frac{J_{r}}{J_{a}}\right)
$$

\subsection{GSI System}

The geological strength index (GSI) was developed by Hoek et al. [53] as an input parameter for the Hoek-Brown criterion to estimate the reduction in rock mass strength for different geological conditions. This classification is simple, fast, and is based on the rock mass appearance and structure. GSI values can be obtained from the quantitative GSI chart proposed by Marinos and Hoek [54].

The evaluations of the 1-1\# stope using Q and GSI systems are summarized in Table 4. The results show that the rock mass classification with the Q-system (shown in Table 4) leads to a more conservative rock mass classification than the RMR system (Table 3).

Table 4. Evaluation results using rock mass quality (Q) and GSI systems.

\begin{tabular}{|c|c|c|c|c|c|c|c|c|c|c|}
\hline \multirow{2}{*}{ Site } & \multicolumn{6}{|c|}{ Rating } & \multirow{2}{*}{$\mathbf{Q}$} & \multirow{2}{*}{$\mathbf{Q}^{\prime}$} & \multirow{2}{*}{$\begin{array}{c}\text { Rock Mass } \\
\text { Quality }\end{array}$} & \multirow{2}{*}{ GSI } \\
\hline & RQD & $J_{n}$ & $J_{r}$ & $J_{a}$ & $J_{w}$ & SRF & & & & \\
\hline $\begin{array}{l}\text { Biotite plagioclase } \\
\text { gneiss }(\mathrm{H} / \mathrm{W})\end{array}$ & 43 & 12 & 3 & 2 & 1 & 1 & 5.38 & 5.38 & Fair & 45 \\
\hline $\begin{array}{l}\text { Chalcopyrite with } \\
\text { pyrite and sphalerite } \\
\text { (Orebody) }\end{array}$ & 55 & 12 & 2 & 2 & 1 & 2 & 2.2 & 4.4 & Poor & 50 \\
\hline $\begin{array}{c}\text { Amphibole } \\
\text { plagiogneiss (F/W) }\end{array}$ & 68 & 12 & 2 & 1 & 1 & 1 & 11.33 & 11.33 & Good & 60 \\
\hline
\end{tabular}

\section{Estimation of Rock Mass Properties}

Rock mass properties such as the Hoek-Brown constants, uniaxial compressive strength $\left(\sigma_{\mathrm{cmass}}\right)$, uniaxial tensile strength $\left(\sigma_{\text {tmass }}\right)$, deformation modulus $\left(E_{\text {mass }}\right)$, and shear strength parameters were calculated using empirical equations based on $\mathrm{RMR}_{89}, \mathrm{Q}$, and GSI.

\subsection{Hoek-Brown Parameters}

The Hoek-Brown failure criterion was used to determine the rock mass properties of the 1-1\# stope. Hoek et al. [55] suggested the following equations for calculating the rock mass constants (i.e., $\left.m_{b}, s, a\right)$ :

$$
\begin{gathered}
m_{b}=m_{i} \exp ^{\left(\frac{G S I-100}{28-14 D}\right),} \\
s=\exp ^{\left(\frac{G S I-100}{9-3 D}\right)}, \\
a=\frac{1}{2}+\frac{1}{6}\left(e^{-G S I / 15}-e^{-20 / 3}\right),
\end{gathered}
$$

where $\mathrm{D}$ is a factor that depends upon the degree of disturbance to which the rock mass has been subjected by blast damage and stress relaxation. $\mathrm{D}$ varies from 0 for undisturbed in-situ rock masses to 1 for very disturbed rock masses. The blasting quality of the 1-1\# stope was determined to be good by field observations. In this study, the value of $\mathrm{D}$ is considered to be 0.6 [55]. The constant $m_{i}$ for 
intact rock can be estimated according to a table published by Marinos and Hoek [54]. The value of $\mathrm{m}_{i}$ is defined as 32 for coarse-grained metamorphic rock. The calculated Hoek-Brown constants are presented in Table 5.

Table 5. Hoek-Brown parameters.

\begin{tabular}{cccc}
\hline \multirow{2}{*}{ Zone } & \multicolumn{3}{c}{ Constants } \\
\cline { 2 - 4 } & $\mathbf{m}_{\mathbf{b}}$ & $\mathbf{s}$ & $\mathbf{a}$ \\
\hline $\mathrm{H} / \mathrm{W}$ & 1.93 & 0.0005 & 0.508 \\
Orebody & 2.49 & 0.0010 & 0.506 \\
$\mathrm{~F} / \mathrm{W}$ & 4.16 & 0.0039 & 0.503 \\
\hline Note: $\mathrm{m}_{\mathrm{b}}, \mathrm{s}$ and a are the rock mass constants.
\end{tabular}

\subsection{Deformation Modulus}

In-situ determination of the deformation modulus of rock mass $\left(E_{\text {mass }}\right)$ is costly and often very difficult because the rock mass is an anisotropic material. Furthermore, the results of individual tests may be markedly different owing to the anisotropy. Alternatively, empirical methods are generally used to estimate $E_{\text {mass }}$ [56]. Various empirical equations and the resulting $E_{\text {mass }}$ values are summarized in Tables 6 and 7, respectively.

Table 6. Empirical equations for calculation of $E_{\text {mass }}$.

\begin{tabular}{|c|c|c|}
\hline Author & Equations (Units GPa) & Number \\
\hline Bieniawski [57] & $E_{\text {mass }}=2 \mathrm{RMR}-100, \mathrm{RMR}>50$ & (7) \\
\hline Serafim and Pereira [58] & $E_{\text {mass }}=10^{(\mathrm{RMR}-10) / 40}, \mathrm{RMR}<50$ & (8) \\
\hline Barton et al. [59] & $E_{\text {mass }}=25 \log _{10} Q, Q>1$ & (9) \\
\hline Nicholson and Bieniawski [60] & $E_{\text {mass }}=\frac{E_{i}}{100}\left(0.0028 \mathrm{RMR}^{2}+0.9 \exp \left(\frac{\mathrm{RMR}}{22.8}\right)\right)$ & $(10)$ \\
\hline Read et al. [61] & $E_{\text {mass }}=0.1(\mathrm{RMR} / 10)^{3}$ & $(11)$ \\
\hline Marinos and Hoek [54] & $E_{\text {mass }}=(1-D / 2) 10^{(\mathrm{GSI}-10) / 40}, \sigma_{c i}>100$ & (12) \\
\hline Ramamurthy [62] & $E_{\text {mass }}=E_{i} \exp (0.8625 \log Q-2.875)$ & (13) \\
\hline Hoek and Diederichs [63] & $E_{\text {mass }}=E_{i}\left(0.02+\frac{1-D / 2}{1+e^{((60+15 D-\mathrm{GSI}) / 11)}}\right)$ & $(14)$ \\
\hline
\end{tabular}

Note: $\sigma_{c i}$ is uniaxial compressive strength of the intact rock (MPa) and $E_{i}$ is the deformation modulus of intact rock $(\mathrm{GPa})$.

Table 7. Estimated deformation modulus $E_{\text {mass }}$ of the rock mass.

\begin{tabular}{cccccccccc}
\hline & \multicolumn{10}{c}{$E_{\text {mass }}(\mathrm{GPa})$} \\
\cline { 2 - 9 } Zone & $\begin{array}{c}\text { Equation } \\
\mathbf{( 7 )}\end{array}$ & $\begin{array}{c}\text { Equation } \\
\mathbf{( 8 )}\end{array}$ & $\begin{array}{c}\text { Equation } \\
\mathbf{( 9 )}\end{array}$ & $\begin{array}{c}\text { Equation } \\
\mathbf{( 1 0 )}\end{array}$ & $\begin{array}{c}\text { Equation } \\
\mathbf{( 1 1 )}\end{array}$ & $\begin{array}{c}\text { Equation } \\
\mathbf{( 1 2 )}\end{array}$ & $\begin{array}{c}\text { Equation } \\
\mathbf{( 1 3 )}\end{array}$ & $\begin{array}{c}\text { Equation } \\
\mathbf{( 1 4 )}\end{array}$ & Average \\
\hline H/W & - & - & 18.3 & 7.6 & 12.5 & 5.2 & 5.4 & 4.6 & 8.9 \\
Ore body & 10.0 & - & 8.6 & 10.2 & 16.6 & 7.0 & 4.2 & 6.9 & 9.1 \\
F/W & 20.0 & - & 26.4 & 11.5 & 21.6 & 12.4 & 7.1 & 12.0 & 15.9 \\
\hline
\end{tabular}

\subsection{Rock Mass Strength}

Different empirical equations were used to calculate the rock mass strength $\left(\sigma_{\mathrm{cmass}}\right)$ on the basis of rock mass classification systems. The most widely used equations are shown in Table 8 . The calculated $\sigma_{\text {cmass }}$ values are given in Table 9. In addition, the tensile strength $\sigma_{\text {tmass }}$ of rock mass is given by [55]:

$$
\sigma_{\text {tmass }}=-s \sigma_{c i} / m_{b} \text {. }
$$

The calculated $\sigma_{\text {tmass }}$ for the $\mathrm{H} / \mathrm{W}$, ore body, and F/W using Equation (15) were 0.028, 0.041, and $0.123 \mathrm{MPa}$, respectively. 
Table 8. Empirical equations for the calculation of $\sigma_{\text {cmass. }}$

\begin{tabular}{ccc}
\hline Author & Equations (Units MPa) & Number \\
\hline Bhasin and Grimstaad [64] & $\sigma_{\text {cmass }}=\left(\sigma_{c i} / 100\right) 7 \gamma Q^{1 / 3}, Q>10$ & $(16)$ \\
Singh [65] & $\sigma_{\text {cmass }}=7 \gamma Q^{1 / 3}, Q<10$ & $(17)$ \\
Trueman [66] & $\sigma_{c m a s s}=0.5 e^{0.06 R M R}$ & $(18)$ \\
Barton [67] & $\sigma_{c \text { cmass }}=5 \gamma\left(Q \frac{\sigma_{c i}}{100}\right)^{1 / 3}$ & $(19)$ \\
Hoek et al. [55] & $\sigma_{\text {cmass }}=\sigma_{c i} \frac{\left(m_{b}+4 s-a\left(m_{b}-8 s\right)\right)\left(m_{b} / 4+s\right)^{a-1}}{2(1+a)(2+a)}$ & $(20)$ \\
Ramamurthy [68] & $\sigma_{\text {cmass }}=\sigma_{c i} \exp ((\operatorname{RMR}-100) / 25)$ & $(21)$ \\
\hline
\end{tabular}

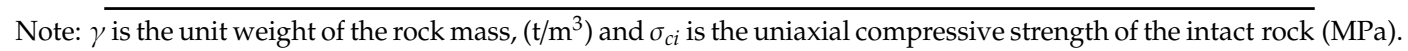

Table 9. Estimated rock mass strength parameters for the 1-1\# stope.

\begin{tabular}{|c|c|c|c|c|c|c|c|c|c|c|}
\hline \multirow{2}{*}{ Zone } & \multicolumn{7}{|c|}{$\sigma_{\text {cmass }}(\mathrm{MPa})$} & \multirow{2}{*}{$\begin{array}{c}\begin{array}{c}\sigma_{\text {tmass }} \\
(\mathrm{MPa})\end{array} \\
\begin{array}{c}\text { Equation } \\
(15)\end{array}\end{array}$} & \multirow{2}{*}{$\begin{array}{c}\mathrm{c}^{\prime}(\mathrm{MPa}) \\
\text { Equation } \\
(22)\end{array}$} & \multirow{2}{*}{$\begin{array}{c}\varphi^{\prime}\left({ }^{\circ}\right) \\
\begin{array}{c}\text { Equation } \\
(23)\end{array}\end{array}$} \\
\hline & $\begin{array}{c}\text { Equation } \\
\text { (16) }\end{array}$ & $\begin{array}{c}\text { Equation } \\
\text { (17) }\end{array}$ & $\begin{array}{c}\text { Equation } \\
\text { (18) }\end{array}$ & $\begin{array}{c}\text { Equation } \\
\text { (19) }\end{array}$ & $\begin{array}{c}\text { Equation } \\
\text { (20) }\end{array}$ & $\begin{array}{c}\text { Equation } \\
\text { (21) }\end{array}$ & Average & & & \\
\hline $\mathrm{H} / \mathrm{W}$ & - & 33.1 & 10.0 & 24.6 & 20.3 & 15.2 & 20.6 & 0.028 & 5.6 & 31.8 \\
\hline $\begin{array}{c}\text { Ore } \\
\text { body }\end{array}$ & - & 38.2 & 13.5 & 27.8 & 21.9 & 17.4 & 23.8 & 0.041 & 5.8 & 34.0 \\
\hline $\mathrm{F} / \mathrm{W}$ & 56.4 & - & 18.3 & 33.3 & 36.3 & 26.8 & 34.2 & 0.123 & 8.8 & 38.3 \\
\hline
\end{tabular}

\subsection{Equivalent Mohr-Coulomb Strength Parameters}

The Mohr-Coulomb strength criterion is available in most geotechnical codes. This sometimes requires a conversion of the Hoek-Brown strength criterion parameters to their equivalent Mohr-Coulomb parameters. The cohesive strength $c^{\prime}$ and internal friction angle $\varphi^{\prime}$ can be calculated by Equations (22) and (23) [55]:

$$
\begin{gathered}
c^{\prime}=\frac{\sigma_{c i}\left[(1+2 a) s+(1-a) m_{b} \sigma_{3 n}\right]\left(s+m_{b} \sigma_{3 n}\right)^{\alpha-1}}{(1+a)(2+a) \sqrt{1+\left(6 a m_{b}\left(s+m_{b} \sigma_{3 n}\right)^{a-1}\right) /((1+a)(2+a))}}, \\
\varphi^{\prime}=\sin ^{-1}\left[\frac{6 a m_{b}\left(s+m_{b} \sigma_{3 n}\right)^{\alpha-1}}{2(1+a)(2+a)+6 a m_{b}\left(s+m_{b} \sigma_{3 n}\right)^{a-1}}\right],
\end{gathered}
$$

where $\sigma_{3 \mathrm{n}}=\sigma_{3 \max } / \sigma_{\mathrm{ci}} \cdot \sigma_{3 \max }$ is the upper limit of the confining stress over the relevant stress ranges between the Hoek-Brown and Mohr-Coulomb criteria. The relationship between $\sigma_{3 \max }$ and $\sigma_{\mathrm{cmass}}$ is:

$$
\frac{\sigma_{3 \max }}{\sigma_{\text {cmass }}}=0.47\left(\frac{\sigma_{\text {cmass }}}{\gamma H}\right)^{-0.94}
$$

where $\sigma_{\text {cmass }}$ is rock mass strength, $\gamma$ is the unit weight of the rock mass, and $H$ is the depth of the excavation below the surface. When the horizontal stress is larger than the vertical stress, the horizontal stress value should replace $\gamma H$. The calculated equivalent Mohr-Coulomb parameter values are given in Table 9.

\section{Empirical Analysis}

Obtaining reliable stability analyses and support capacity predictions is one of the most difficult tasks in rock engineering [69]. In the following section, we present methods for stability analyses and support design of the 1-1\# stope at the Hongtoushan mine based on empirical and numerical methods.

\subsection{Stability Analysis}

The critical span curve [13] was developed to evaluate roof stability in cut-and-fill mines on the basis of 172 data sets classified with Bieniawski's 1976 RMR classification system $\left(\mathrm{RMR}_{76}\right)$ for rock 
mass ranging from $60-80$ or good rock. In 2003, the database was updated with 292 data sets: more than $60 \%$ of the databases consist of good rock, and less than $10 \%$ and $20 \%$ with $\mathrm{RMR}_{76}$ below 40 and 55, respectively (see Figure 6) [15]. Figure 6 illustrates the span design curve for stope stability where it can be seen that at an $\mathrm{RMR}_{89}$ value of 55 and span of $20 \mathrm{~m}$, the 1-1\# stope was located in the unstable zone. It is imperative for mines to adopt precautionary measures when utilizing the empirical design tools for actual design owing to variability in field conditions and ground support systems.

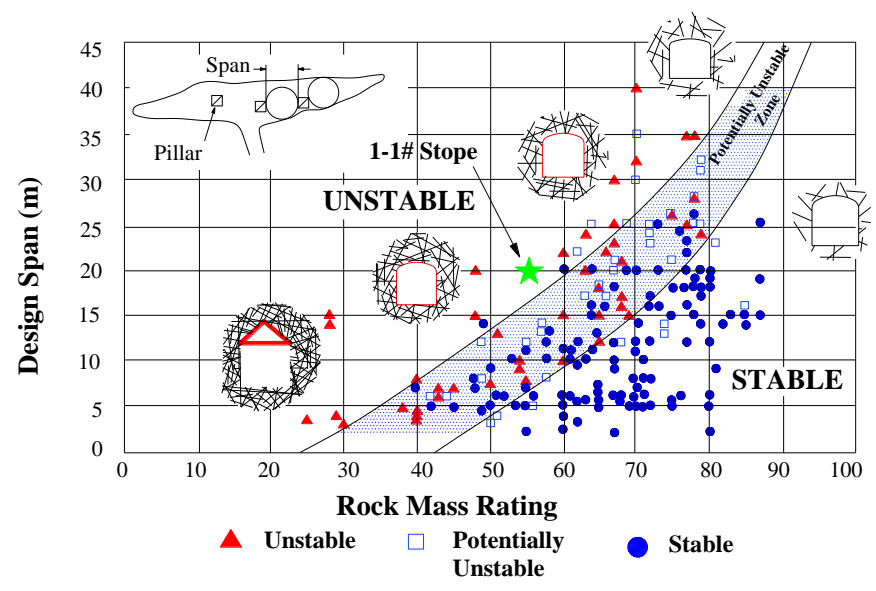

Figure 6. Stability of the 1-1\# stope based on the updated critical span curve [15].

The stability graph is an empirical design tool regularly used to estimate the stability of mining excavations. The initial stability graph was devised by Mathews [3] based on 50 case histories and has since been modified several times. At present, the stability graph proposed by Nickson [5] is widely used.

The stability graph relates two calculated factors: (1) the stability number ( $\mathrm{N}^{\prime}$; Equation (25)), which represents the competency of the rock mass for a given stress condition, and (2) the hydraulic radius (HR), which accounts for stope geometry.

The modified stability number, $\mathrm{N}^{\prime}$, presented by Potvin [4], is expressed by:

$$
N^{\prime}=Q^{\prime} \times A \times B \times C,
$$

where $\mathrm{A}$ is the rock stress factor, $\mathrm{B}$ is the joint orientation adjustment factor, and $\mathrm{C}$ is the gravity adjustment factor. $\mathrm{Q}^{\prime}$ is obtained from Equation (3).

The rock stress factor, $\mathrm{A}$, reflects the stresses acting on the free surfaces of open stopes and is determined from the ratio of the intact rock strength (Table 3) and induced stress at the surface center-line [4]. The induced stress is determined using a linear-elastic numerical model. The boundary conditions and rock mass parameters of the 1-1\# stope numerical model are in accordance with Section 7 (see below) except that the linear-elastic model is used instead of the Mohr-Coulomb model. The results show that the induced stress on the 1-1\# stope roof was $29 \mathrm{MPa}$. The value of A was then calculated to be 0.28 .

The joint orientation adjustment factor, B, accounts for the influence of joints on the stability of the stope faces [4]. Most structurally controlled failures occur along critical joints (dip direction/dip: $180^{\circ} / 45^{\circ}$ ), which form a wedge angle with the free surface (Table 1) to be broken by another joint set, blasting, or stress. The obtained B factor had a value of 0.5 .

The final factor, $C$, is an adjustment for the effect of gravity [4]. Failure can occur from the roof by gravity-induced falls. The obtained $\mathrm{C}$ factor had a value of 2 .

The value of $\mathrm{N}^{\prime}$ at the 1-1\# stope roof is given in Table 10. 
Table 10. Stability number $\left(\mathrm{N}^{\prime}\right)$ of the 1-1\# stope roof.

\begin{tabular}{cccccc}
\hline Zone & $\mathbf{Q}^{\prime}$ & $\mathbf{A}$ & $\mathbf{B}$ & $\mathbf{C}$ & $\mathbf{N}^{\prime}$ \\
\hline Stope Roof & 4.4 & 0.28 & 0.50 & 2 & 1.23 \\
\hline
\end{tabular}

The HR measures the combined influence of the stope size and shape on the excavation stability by dividing the stope area by the perimeter of that particular face:

$$
H R=a / l,
$$

where $a$ is the stope roof area and $l$ is the stope perimeter.

The HR is frequently used to quantify surface geometry for assessing regular underground stability. However, for irregular stope geometries, the surface center cannot be easily determined [70]. In particular, pillars and raises are designed or maintained in entry open stopes, and calculation of the HR of such stopes is difficult. The effective radius factor (ERF) was developed by Milne et al. [71] for a given stope surface and is used to assess the stability of a stope with pillars or raises. As illustrated in Figure 7, for any rays that intersect with the stope boundary, the distance between pillar to stope boundary is treated to be of infinite length. The ERF value should not be calculated less than the average block size of the rock mass away from the pillar or raise. An AutoCad 'Lisp' program written by Lunder at the Noranda Technology Centre (NTC) automatically calculates radius factor values for any point on a surface using any angular increment [71]. The program recognizes the presence of a pillar or raise and calculates the ERF as a replacement for HR (Equation (27)).

The calculated maximum ERF value was 7.62, and the 1-1\# stope results are plotted in Figure 8. The stope plots in the "stable with support zone" and adjacent to the "supported transition zone" curve. The results show that an unsupported stope was unstable when extraction occurred in the 1-1\# stope and that supports were therefore needed.

For an irregular stope with pillars and raises, the calculated ERF can be expressed as [69]:

$$
\mathrm{ERF}=\frac{0.5}{\frac{1}{n} \sum_{\theta=1}^{n} \frac{1}{r_{\theta}}},
$$

where $r_{\theta}(m)$ is the distance from the surface center to the abutments at angle $\theta$, and $\mathrm{n}$ is the number of rays measured to the surface edge.

\subsection{Support Design}

Considering the overhand cut-and-fill mining scenarios, rock mass quality, induced stress, and large-span effects, typical stope support systems can be obtained on the basis of the cable bolt design graph.

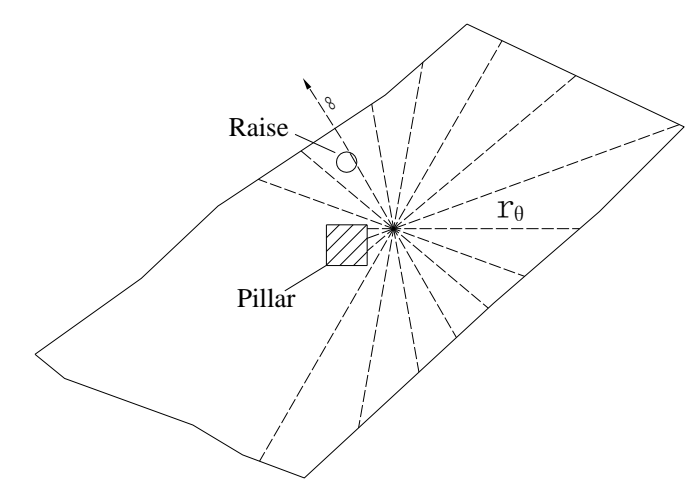

Figure 7. Rays used for calculating the radius factor of the 1-1\# stope roof with a pillar and raise [65]. 


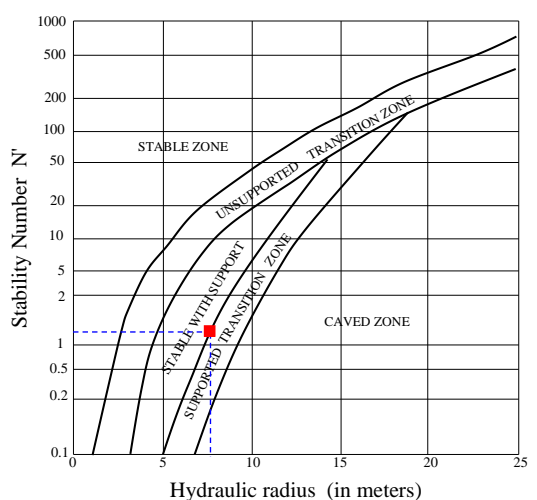

Figure 8. Stability of the 1-1\# stope based on the stability graph [5].

\subsubsection{Cable Bolt Density}

The purpose of the cable bolt support is to prevent falling along existing discontinuities in the 1-1\# stope. Cable bolt requirements are determined using the empirical cable bolt design graph and considering the worst-case scenario. The cable bolt density is related to jointing frequency through the block size (parameter RQD/Jn $/ \mathrm{J}_{\mathrm{n}}$. The ratio of block size (parameter RQD $/ \mathrm{J}_{\mathrm{n}}$ ) and HR of the stope surface are important parameters for determining the cable bolt support density. Figure 9a illustrates the relationship between cable bolt density and relative block size factor, $\mathrm{RQD} / \mathrm{J}_{\mathrm{n}} / \mathrm{HR}$. Line $2 \#$ reflects a conservative design zone based on maintaining $100 \%$ stability above the line. This corresponds closely with the density of 0.18 cable bolts $/ \mathrm{m}^{2}$ for entry mining presented in Figure 9a for stability of the 1-1\# stope roof support. The information obtained from the empirical methods can be combined with mechanistic assumptions and logic to develop a sounder semi-empirical design methodology. Hutchinson and Diederichs [36] proposed the cable bolt spacing design graph shown in Figure 9b on the basis of this approach. The cable bolt support density is listed in Table 11.

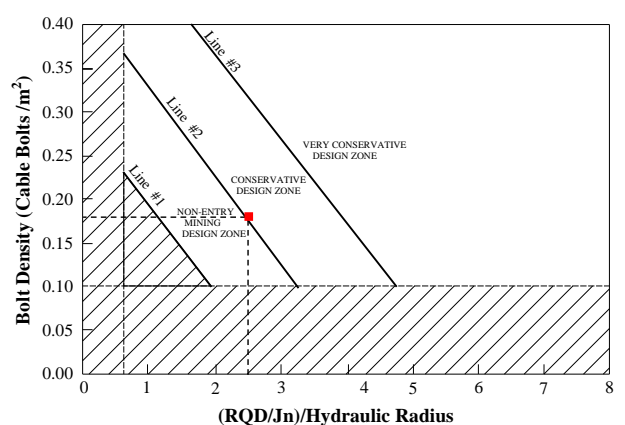

(a)

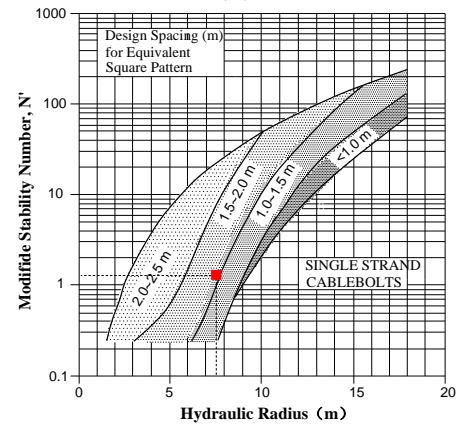

(b)

Figure 9. Cable bolt density for back support with application to the 1-1\# stope. (a) Revised design graph for cable bolt density [70]; (b) Recommended spacing for single strand cables [36]. 
Table 11. Cable bolt support density for the 1-1\# stope roof.

\begin{tabular}{cc}
\hline Author & Cable Bolt Density \\
\hline Potvin and Milne [72] & $2.3 \mathrm{~m} \times 2.3 \mathrm{~m}$ \\
Hutchinson and Diederichs [36] & $1.5 \mathrm{~m} \times 1.5 \mathrm{~m} \sim 2.5 \mathrm{~m} \times 2.5 \mathrm{~m}$ \\
\hline
\end{tabular}

\subsubsection{Cable Bolt Length}

The design of the cable bolt length is related to stope dimensions. The length of a cable bolt should reach far enough into the undisturbed ground to ensure a proper anchor and permit cable anchorage in competent rock beyond a potential failure zone [4]. The cable bolt length (L) is difficult to determine and some empirical values have been suggested in Table 12. Figure 10a shows the design line proposed by Potvin et al. [73]. The cable bolt length is related to the HR of the supported surface for the stope roof. The modified version of this graph for cable bolt support design is shown in Figure 10b, published by Hutchinson and Diederichs [36]. A deep large-span stope may produce a situation where cables cannot be anchored beyond a potential failure zone. The length selection of a cable bolt should therefore account for the height of the remaining ore body.

The calculated cable bolt length for the 1-1\# stope roof is presented in Table 12. Combining with the 1-1\# stope scenario condition, the cable bolt length of the 1-1\# stope roof was $9 \mathrm{~m}$ and the cable bolt grid was $2.0 \mathrm{~m} \times 2.0 \mathrm{~m}$. A site-specific design may be required in the event of an unfavorable structure and the presence of wedges.

According to the analysis presented in Section 6.2, the recommended cable bolt support system needs to be verified by other approaches including numerical analyses, which are presented in Section 7 . The adequacy of the empirical design was then further assessed from an engineering perspective for the observed ground conditions.

Table 12. Support length of the cable bolt for the 1-1\# stope roof.

\begin{tabular}{lll}
\hline Author & Equations (Units m) & Calculated Cable Bolt Lengths/m \\
\hline Lang and Bischoff [42] & $\mathrm{L}=(0.67) \operatorname{Span}^{0.67}$ & 4.98 \\
Bieniawski et al. [43] & $\mathrm{L}=\mathrm{Span} / 3$ & 6.67 \\
Potvin et al. [73] & $\mathrm{L}=1.5 \times \mathrm{HR}$ & 11.43 \\
Hutchinson and Diederichs [36] & & $9-13$ \\
\hline
\end{tabular}

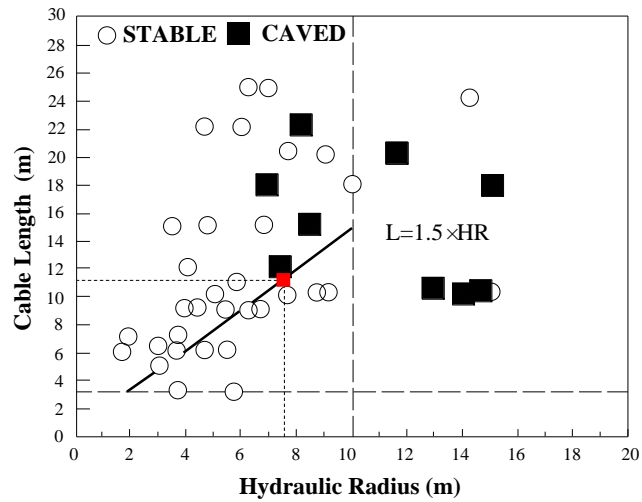

(a)

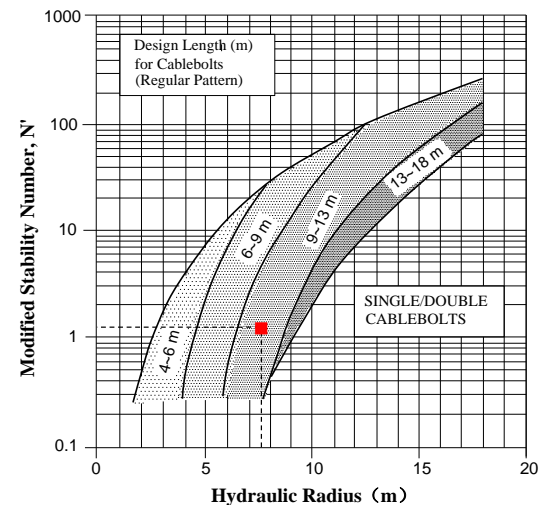

(b)

Figure 10. Cable bolt length for back support with application to the 1-1\# stope. (a) Cable bolt length for back support [73]; (b) Recommended minimum lengths for a cable bolt [36].

\section{Numerical Analysis}

To verify the empirical results presented in Section 6, FLAC3D (fast Lagrange analysis of continua in 3D) [74] was created to investigate the roof deformation, plastic zones distribution, and tensile stress 
distribution around the unsupported and supported roof during the mining sequence. UNWEDGE [75] was used to calculate the safety factor of the unsupported and supported wedge at the roof.

\subsection{FLAC3D Simulation}

The geometric indexes of the 1-1\# stope shown in Figure 3 were $50 \mathrm{~m}$ long in strike, $20 \mathrm{~m}$ wide, $36 \mathrm{~m}$ in vertical height, and the stope was inclined at $75^{\circ}$ from horizontal. To minimize boundary effects in the mining sequence, the model was created with dimensions of $250 \mathrm{~m}$ long, $140 \mathrm{~m}$ wide, and $140 \mathrm{~m}$ high with the generated numerical model illustrated in Figure 11. A denser mesh was adopted around the excavation. A total of 159,000 zones and 168,116 grids were defined. The rock mass was assumed to be "ideal" elastic-plastic material, and the rock mass and backfill properties were obtained from the estimated values given in Sections 3 and 5. The Mohr-Coulomb strength criterion was used to identify elements undergoing yielding and plastic behavior in the stope surface. The rock mass was simplified to an equivalent isotropic medium.

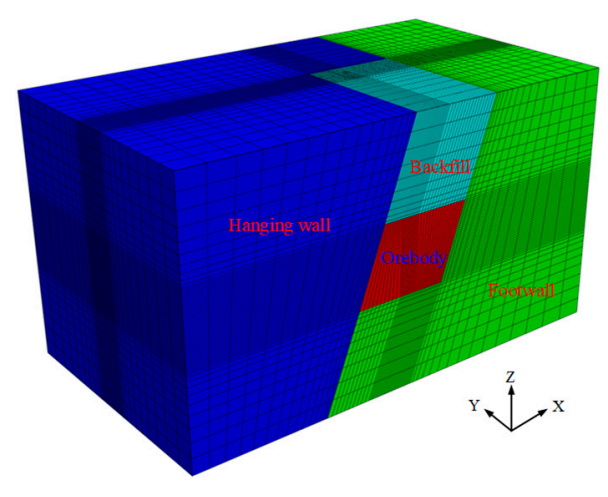

(a) Three-dimensional numerical mode

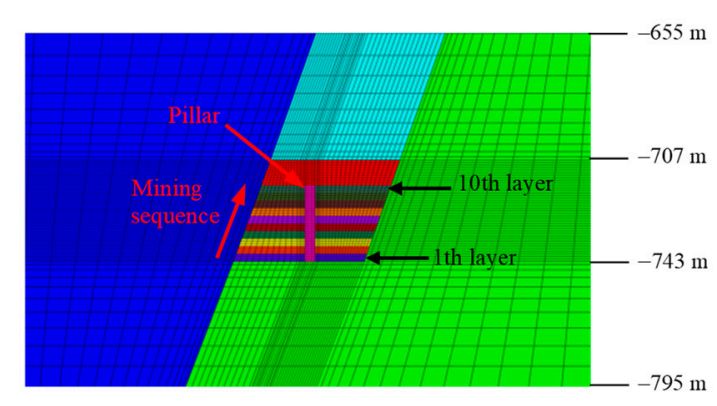

(b) Vertical section in the $x-z$ plane

Figure 11. Three-dimensional numerical model of the 1-1\# stope.

In the stress initialization, the bottom boundary of the model was restrained in all directions. The horizontal displacements of the four vertical planes of the model were restricted in the normal direction, and in-situ stresses obtained in Section 2.3 were applied to other boundaries (i.e., top, left, and front boundaries). The major horizontal stress axis was perpendicular to the strike of the ore body, the minor horizontal stress axis was parallel to the strike of ore body in the mining face plane, and the vertical stress was applied on the upper boundary.

The numerical models include 10 mining steps. The mining and backfilling sequence fills the previous layer with cemented tailings after mining the next layer. The mining sequence is explained and shown in Figure 11b. This analysis included both unsupported and supported cases. While the stope surface of the top layer was mined in up to 10 steps during mining, the numerical results show the displacement, tensile stress, and plastic zone distribution in each mining step (Figures 12 and 13). The tensile stresses and vertical displacement field of the 1-1\# stope roof for the unsupported case 
are presented in Figure 12. The tensile stress in the roof reduced abruptly after mining the first layer and then continuously increased at a rate of about $0.05 \mathrm{MPa}$. After mining in the $9^{\text {th }}$ layer, the tensile stress in the stope roof increased abruptly to $0.594 \mathrm{MPa}$, at which point the tensile stress was greater than its calculated tensile stress (0.041 MPa). After the 10th (and last) layer was mined, the tensile stress in the roof reached $0.752 \mathrm{MPa}$ (Figure 12a). The maximum plastic zone thickness reached $5 \mathrm{~m}$ under the unsupported conditions (Figure 13a). The vertical displacement at stope roof is shown in Figure $12 \mathrm{~b}$. The vertical displacement at stope roof increased with mining activity and the maximum vertical displacement at the roof reached $68.2 \mathrm{~mm}$ (Figure 13a).

The recommended cable bolt support pattern was applied to the 1-1\# stope roof according to Section 6.2. The parameters of the cable bolt structure unit are listed in Table 13. For the supported cases, Figure 13b and Table 14 show that the maximum vertical displacement and plastic zone thickness decreased significantly compared with unsupported cases. The displacement was reduced to $18.6 \mathrm{~mm}$ and the maximum thickness of the plastic zone was reduced to $2 \mathrm{~m}$. After the 10th layer was mined, the laser distance meter was employed to survey subsidence displacement of the supported roof. The monitored vertical displacement of the stope roof in two month is shown in Figure 14 . The maximum vertical displacement was approximately $12.5 \mathrm{~mm}$. Mining of the 1-1\# stope was successfully completed using an overhand cut-and-fill mining method and had not shown any signs of failure. The numerical results were consistent with the field observations for a supported stope.

Table 13. Parameters of the cable bolt structure unit.

\begin{tabular}{ccccccccc}
\hline Material & $\begin{array}{c}\text { Density } \\
\left(\mathbf{k g} / \mathbf{m}^{\mathbf{3}} \mathbf{)}\right.\end{array}$ & $\begin{array}{c}\text { Young's } \\
\text { Modulus } \\
\mathbf{( G P a )}\end{array}$ & $\begin{array}{c}\text { Cross- } \\
\text { Sectional } \\
\text { Area } \\
\mathbf{( m}^{\mathbf{2}} \mathbf{)}\end{array}$ & $\begin{array}{c}\text { Tensile } \\
\text { Strength } \\
\mathbf{( M P a})\end{array}$ & $\begin{array}{c}\text { Grout } \\
\text { Stiffness } \\
\mathbf{( N / m )}\end{array}$ & $\begin{array}{c}\text { Grout } \\
\text { Cohesion } \\
\mathbf{( N / m )}\end{array}$ & $\begin{array}{c}\text { Grout } \\
\text { Friction } \\
\text { Angle }\left(^{\circ}\right)\end{array}$ & $\begin{array}{c}\text { Grout } \\
\text { Outer } \\
\text { Perimeter } \\
(\mathbf{m})\end{array}$ \\
\hline $\begin{array}{c}\text { Cable } \\
\text { bolt }\end{array}$ & 7800 & 202 & $\begin{array}{c}2.49 \times \\
10^{-4}\end{array}$ & 1860 & $\begin{array}{c}1.05 \times \\
10^{10}\end{array}$ & $2.0 \times 10^{4}$ & 25 & 0.176 \\
\hline
\end{tabular}
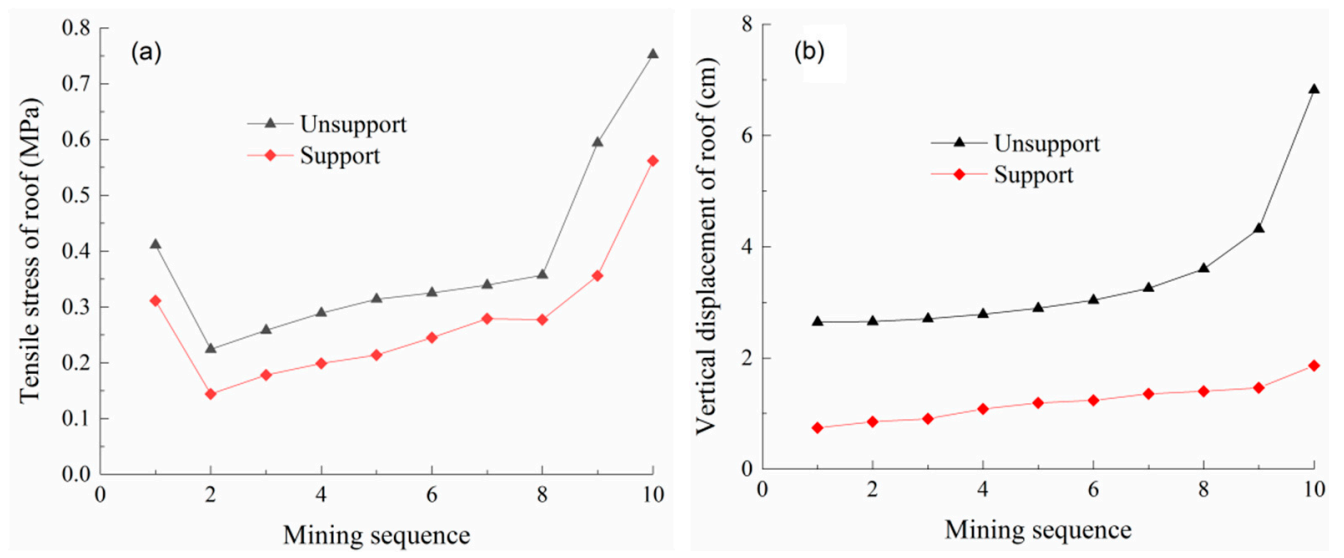

Figure 12. Tensile stress and vertical displacement distribution of the 1-1\# stope roof with mining sequence. (a) Tensile stress of roof; and (b) Vertical displacement of roof. 


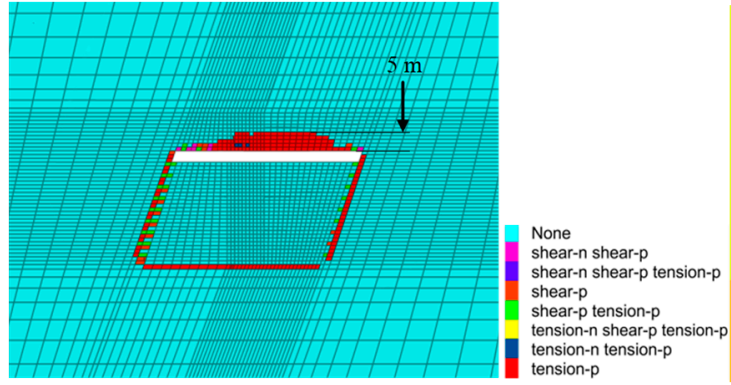

Plastic zone distribution

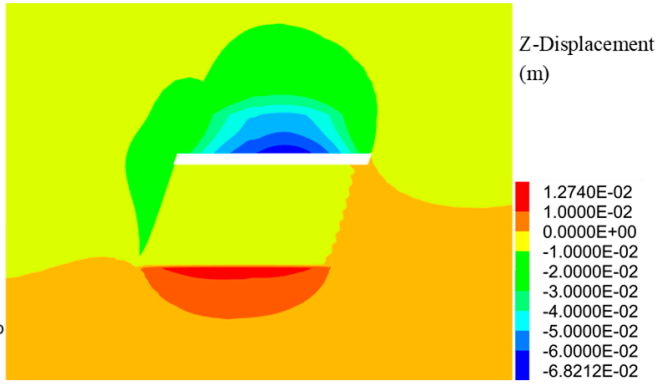

z-displacement

(a) Unsupported

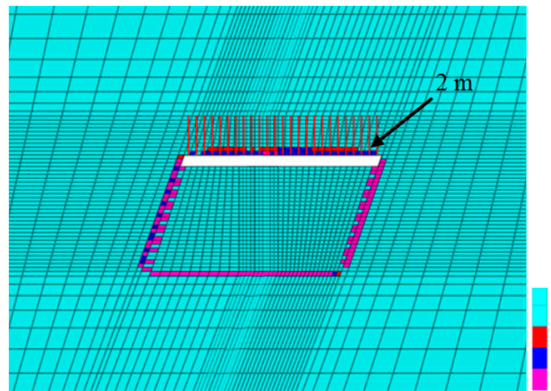

Plastic zone distribution

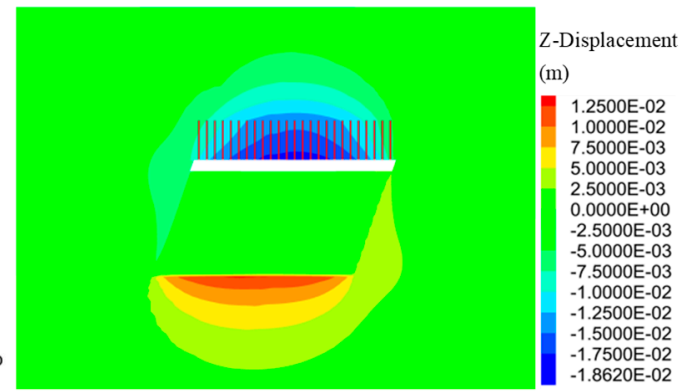

z-displacement

(b) Supported

Figure 13. Thickness of the plastic zone and vertical displacement for unsupported and supported cases.

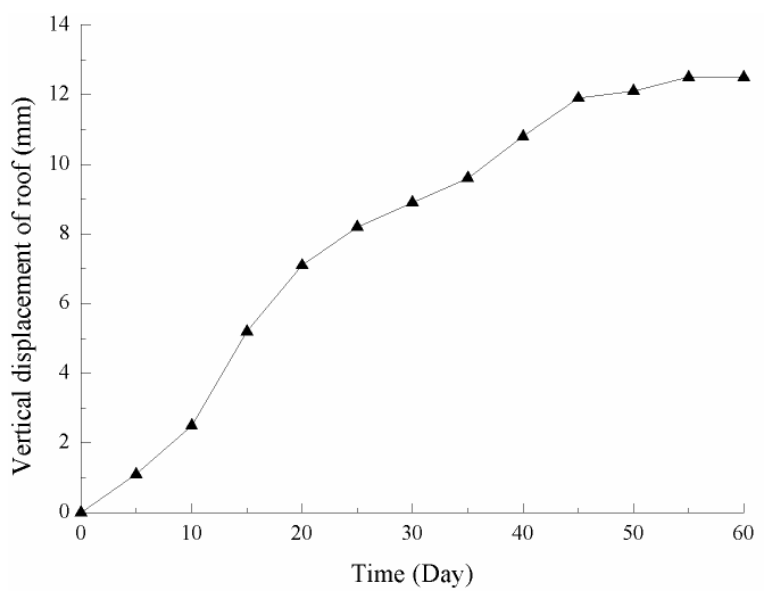

Figure 14. Monitored vertical displacement of the 1-1\# stope roof.

Table 14. Maximum plastic zone thickness and vertical displacement of the roof obtained from FLAC3D.

\begin{tabular}{ccccc}
\hline \multirow{2}{*}{ Zone } & \multicolumn{2}{c}{ Maximum Thickness of Plastic Zone (m) } & \multicolumn{2}{c}{ Maximum Vertical Displacement (mm) } \\
\cline { 2 - 5 } & Unsupported & Supported & Unsupported & Supported \\
\hline Roof & 5 & 2 & 68.2 & 18.6 \\
\hline
\end{tabular}

\subsection{UNWEDGE Simulation}

The failure in the 1-1\# stope is known to be structurally controlled by larger-scale structures presented in the roof. The wedges are formed by intersecting structural features; one or more of 
wedges can fall from the roof if the continuous boundaries planes are broken. The wedge failures are the most common failure type at the Hongtoushan mine.

The three-dimensional wedges are formed by the intersections of three or more joint planes on the excavation boundary of the opening $[76,77]$. There are three discontinuity sets in the 1-1\# stope roof. Therefore, the wedge block analysis was conducted using the UNWEDGE code [75] for the 1-1\# stope roof using the joint data provided in Section 3. The wedge block in the stope roof is shown in Figure 15a. The numerical results show that the apex height of a large wedge block in the stope roof was $2.81 \mathrm{~m}$, the safety factor was 0 , and the failure mode was the falling wedge. Thus, to ensure the stability of the 1-1\# stope roof, cable bolt support was required.

Conditions were automatically checked using UNWEDGE [75] after the recommended cable bolt support pattern was installed at the roof, as shown in Figure 15b. The safety factor of supported wedge block of the roof was 1.6, which indicates that the supported wedge block was stable and had no potential wedge failure. Figure 16 is part of the cable bolt installed in field.
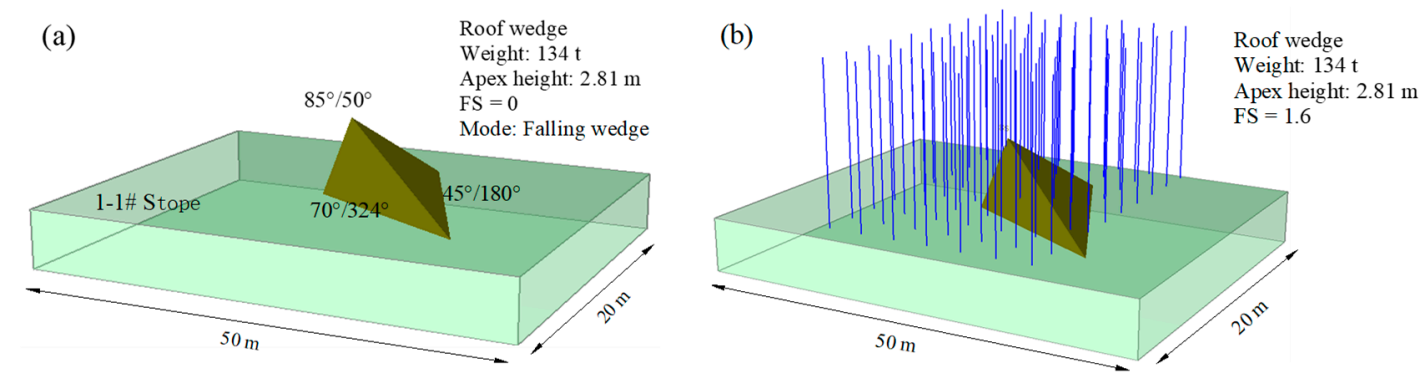

Figure 15. The stability of the unsupported and supported wedge blocks in the 1-1\# stope roof. (a) Unsupported wedge block; and (b) Supported wedge block.

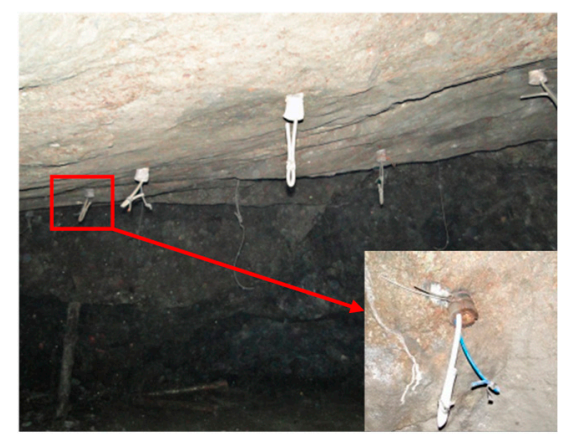

Figure 16. Cable bolt pattern to stabilize the roof wedge block.

\section{Discussion}

This article is a contribution to the stability analyses and cable bolt support design for deep large-span stope at the Hongtoushan mine with complicated geological condition using an integrated empirical and numerical method. The RMR and stability graph are the most widely used empirical methods, which are familiar by rock engineers and have gained a universal acceptance. The empirical methods based on detailed geological surveys and they have been applied to many construction designs. However, these empirical methods cannot adequately provide the stress, displacement, plastic zone distribution, or safety factor information for deep large-span stopes. Therefore, a particular attention has to be given when they are used. In particular, determination of mechanical parameters for jointed rock mass is very sensitive to the field observations. Meanwhile, numerical methods such as the finite difference method are very dependent on the strength parameters of the rock masses. Therefore, both methods should be used with caution and these parameters should be determined reliably according to field data. On the other hand, providing reliable input parameters to numerical methods can produce meaningful calculations on the ground control. In this paper, two methods 
were used to obtain quantitative stability assessment and optimum cable bolt support design for deep large-span stope roofs.

As mining activity progressed upwards from one layer to another, the tensile stress of the roof had a law of decreasing first and then increasing, and it was always greater than the calculated tensile stress. This was mainly due to the roof being in the relaxation zone after mining the first layer, leading to roof tensile stress being reduced abruptly. As the upper part of the 1-1\# stope was the backfill material, the thickness of the remaining ore body continued to decrease during mining, leading to the roof tensile stress continuously increased. In particular, the roof tensile stress increased abruptly when the remaining ore body thickness was reduced to a certain value. Typical cable bolt support systems can be obtained from empirical methods. The long grouting cable bolt support was used in 1-1\# stope. The diameter of the cable bolt and cable bolt hole were $17.8 \mathrm{~mm}$ and $55 \mathrm{~mm}$, respectively. The long grouting cable bolt was installed in the cable bolt hole by means of cement binders, and it was fixed in the hole along its entire length by applying a suitable cement binder and on the friction principle. The numerical methods verify the feasibility of recommended cable bolt support system. The results proved that the empirical and numerical methods agreed with each other.

Although an integrated empirical and numerical method can address geological and geotechnical uncertainties to a certain extent and is easy to use for engineers. It may be invalid in areas where there is damage owing to blasting or a sudden change in geology, occurrence of weak zones, and so on. Measurements should therefore be carried out during extraction to verify the rock mass behavior and check the validity of the proposed support system or to adapt the support system design. After blasting and mucking, the laser distance meter was employed to survey subsidence displacement of the supported roof. The maximum vertical displacement of the stope roof was $12.5 \mathrm{~mm}$, and verified the rationality of the support systems, obtained from a combination of empirical and numerical methods. However, a deep understanding of the internal stress and displacement of the stope roof on the basis of the above monitoring date is difficult. The multi-point borehole extensometer, stress detector, and microseismic monitoring system should also be carried out during mining.

\section{Conclusions}

In this research, both the empirical and numerical methods were conducted for stability analysis and cable bolt support design of a deep large-span stope at the Hongtoushan mine in China. On the basis of engineering geological interpretations and considerations together with field investigations, the rock mass surrounding the 1-1\# stope was classified by the Q, RMR, and GSI rock mass classification systems. The rock mass properties used as input data for the numerical modeling were obtained from empirical equations related to rock mass classification systems and Hoek-Brown constants. Some stability problems were observed for deep large-span stope roofs according to the results obtained from the empirical and numerical methods in consideration of the rock mass quality, induced stress, and large-span effects. According to the results obtained from empirical methods, with the internationally accepted cable bolt design graph. The long grouting cable bolt as support elements were recommended. As verified with the FLAC3D and UNWEDGE codes, the recommended cable bolt support system was feasible. After support installation, the maximum displacement was reduced from 62.8 to $18.6 \mathrm{~mm}$, the maximum thickness of the plastic zone was reduced from 5.0 to $2.0 \mathrm{~m}$, and the safety factor of the unstable wedge blocks was increased from 0 to 1.6, and there was no sign of rock falls. The results of this research proved that the empirical and numerical methods agreed with each other. Field measurements showed the maximum vertical displacement of the stope roof was $12.5 \mathrm{~mm}$, and verified the rationality of the support systems. The integrated empirical and numerical method was therefore suggested to obtain quantitative stability assessment and optimum cable bolt support design for deep large-span stope roofs. It is applicable in other mines and only needs to derive the geotechnical properties rock masses according to the detailed geological survey and laboratory test. 
Author Contributions: X.Z. conceived and designed the research. H.L. performed the field investigations and experiments, presented the supporting scheme and numerical simulation. X.Z. and H.L. wrote the original manuscript. S.Z. and X.Y. participated in the data analysis and manuscript modification.

Acknowledgments: This work was supported by the Project of NSFC-Shandong Joint Fund (U1806208) and National Key Research and Development Program (2016YFC0600803, 2018YFC0604401 and 2018YFC0604604). The authors sincerely thank John Hadjigeorgiou for his valuable advice and inspiration.

Conflicts of Interest: The authors declare no conflict of interest.

\section{References}

1. Wang, W.C.; Cen, W.; Ba, L. Fault tree analysis of roof falling accident in mine. J. Met. Min. 2010, 3, $142-144$. (In Chinese)

2. Sun, X.F. Study on Mechanized Panel Scicing Filling Mining. Master's Thesis, Central South University, Changsha, China, 2003. (In Chinese).

3. Mathews, K.E.; Hoek, E.; Wyllie, D.C.; Stewart, S.B.V. Prediction of Stable Excavations for Mining at Depth Below 1000 Metres in Hard Rock; CANMET Report DSS Serial No. OSQ80-00081, DSS File No. 17SQ.23440-0-9020; Department of Energy, Mines and Resources: Ottawa, ON, Canada, 1981; p. 39.

4. Potvin, Y. Empirical Open Stope Design in Canada. Ph.D. Thesis, University of British Columbia, Vancouver, BC, Canada, 1988.

5. Nickson, S.D. Cable Support Guidelines for Underground Hard Rock Mine Operations. Master's Thesis, University of British Columbia, Vancouver, BC, Canada, 1992.

6. Stewart, S.B.V.; Forsyth, W.W. The Mathews method for open stope design. CIM Bull. 1995, 88, 45-53.

7. Hadjigeorgiou, J.; Grenon, M.; Lessard, J.F. Defining in-situ block size. CIM Bull. 1998, 91, 72-75.

8. Trueman, R.; Mikula, P.; Mawdesley, C.; Haries, N. Experience in Australia with the application of the Mathews method for open stope design. CIM Bull. 2000, 93, 162-167.

9. Bewick, R.; Kaiser, P. Numerical Assessment of Factor B in Mathews Method for Open Stope Design. In Proceedings of the 3rd CANUS Rock Mechanics Symposium, Toronto, ON, Canada, 11-33 May 2009.

10. Swart, A.H.; Handley, M.F. The design of stable stope spans for shallow mining operations. J. S. Afr. Inst. Min. Metall. 2005, 105, 275-286.

11. Sunwoo, C.; RAO, K.U.M. Stability assessment in wide underground mine openings by Mathews' stability graph method. Tunn. Undergr. Space Technol. 2006, 21, 246-252. [CrossRef]

12. Jordá-Bordehore, L.; Martín-García, R.; Alonso-Zarza, A.M.; Jordá-Bordehore, R.; Romero-Crespo, P.L. Stability assessment of shallow limestone caves through an empirical approach: Application of the stability graph method to the Castañar Cave study site (Spain). Bull. Eng. Geol. Environ. 2016, 75, 1469-1483. [CrossRef]

13. Lang, B.D.A. Span Design for Entry-Type Excavations. Ph.D. Thesis, University of British Columbia, Vancouver, BC, Canada, 1994.

14. Wang, J.; Milne, D.; Pakalnis, R. Application of a neural network in the empirical design of underground excavation spans. Min. Technol. 2002, 111, 73-81. [CrossRef]

15. Ouchi, A.M.; Pakalnis, R.; Brady, T.M. Update of span design curve for weak rock masses. In Proceedings of the 99th Annual AGM-CIM Conference, Edmonton, AB, Canada, 27 Apirl-1 May 2004.

16. Idris, M.A.; Saiang, D.; Nordlund, E. Numerical analyses of the effects of rock mass property variability on open stope stability. In 45th US Rock Mechanics/Geomechanics Symposium; American Rock Mechanics Association: Overland Park, KS, USA, 2011.

17. Li, Q.; Chen, L.; Sui, Z.; Wang, L.; Dong, J. Dynamic analysis and criterion evaluation on rockburst considering the fractured dissipative energy. Adv. Mech. Eng. 2019, 11, 1687814019825906. [CrossRef]

18. Li, Q.; Qiao, L.; Dasgupta, G.; Ma, S.; Wang, L.; Dong, J. Blasting vibration safety criterion analysis with equivalent elastic boundary: Based on accurate loading model. Shock. Vib. 2015, 2015, 604683. [CrossRef]

19. Yang, Z.; Zhai, S.; Gao, Q.; Li, M. Stability analysis of large-scale stope using stage subsequent filling mining method in Sijiaying iron mine. Chin. J. Rock Mech. Geotech. Eng. 2015, 7, 87-94. (In Chinese) [CrossRef]

20. Heidarzadeh, S.; Saeidi, A.; Rouleau, A. Evaluation of the effect of geometrical parameters on stope probability of failure in the open stoping method using numerical modeling. Int. J. Min. Sci. Technol. 2019, 29, 399-408. [CrossRef] 
21. Grenon, M.; Hadjigeorgiou, J. Open stope stability using 3D joint network. Rock Mech. Rock Eng. 2003, 36, 183-208.

22. Gao, K.; Wang, L.; Du, C.; Li, J.; Dong, J. Research on the effect of dip angle in mining direction on drum loading performance: A discrete element method. Int. J. Adv. Manuf. Technol. 2017, 89, 2323-2334. [CrossRef]

23. Su, J.H. Application of artificial neural network in optimization of mining structure parameters. Min. Res. Dev. 2002, 22, 27-29. (In Chinese)

24. Zhao, G.Y.; Wang, J.; Wang, S.; Wang, X.R. Analysis of stability of under sea stope roof based on fuzzy-ideal point method. Chin. J. Saf. Sci. 2012, 22, 64-70. (In Chinese)

25. Hu, J.H.; Chun, Y.; Zhou, K.P.; Li, J.L.; Feng, G. Stability of undercut space in fragment orebody based on key block theory. Trans. Nonferrous Met. Soc. China 2016, 26, 1946-1954. [CrossRef]

26. Yang, P.; Li, L.; Aubertin, M. Stress ratios in entire mine stopes with cohesionless backfill: A numerical study. Minerals 2017, 7, 201. [CrossRef]

27. Ma, C.Q.; Li, H.Z.; Zhang, P.P. Subsidence prediction method of solid backfilling mining with different filling ratios under thick unconsolidated layers. Arab. J. Geosci. 2017, 10, 511. [CrossRef]

28. Liu, J.; Liu, Z.; Wang, S.; Shi, C.; Li, Y. Analysis of microseismic activity in rock mass controlled by fault in deep metal mine. Int. J. Min. Sci. Technol. 2016, 26, 235-239. [CrossRef]

29. Jia, H.S.; Wang, L.Y.; Liu, S.W.; Feng, Z.Y.; Fu, M.X. Design of multi-layer coupling support and span of setup entry roof at depth. Arab. J. Geosci. 2018, 11, 488. [CrossRef]

30. Zhang, Z.; Shimada, H.; Sasaoka, T.; Hamanaka, A. Stability control of retained goaf-side gateroad under different roof conditions in deep underground y type longwall mining. Sustainability 2017, 9, 1671. [CrossRef]

31. Mu, W.; Li, L.; Yang, T.; Yu, G.; Han, Y. Numerical investigation on a grouting mechanism with slurry-rock coupling and shear displacement in a single rough fracture. Bull. Eng. Geol. Environ. 2019, 78, 1-19. [CrossRef]

32. Bieniawski, Z.T. Engineering Rock Mass Classifications: A Complete Manual for Engineers and Geologists in Mining, Civil, and Petroleum Engineering; Wiley: New York, NY, USA, 1989; pp. 45-61.

33. Barton, N. Some new Q-value correlations to assist in site characterisation and tunnel design. Int. J. Rock Mech. Min. Sci. 2002, 39, 185-216. [CrossRef]

34. Fuller, P.G. The potential for cable support of open stopes. In Proceedings of the 5th ISRM International Society for Rock Mechanics and Rock Engineering, Melbourne, Australia, 10-15 April 1983.

35. Barton, N. Rock mass classification, tunnel reinforcement selection using the Q-system. In Rock Classification Systems for Engineering Purposes; ASTM International: West Conshohocken, PA, USA, 1987.

36. Hutchinson, D.J.; Diederichs, M.S. Cablebolting in Underground Mines; BiTech Publishers: Richmond, BC, Canada, 1996; pp. 233-240.

37. Hutchinson, D.J.; Falmagne, V. Observational design of underground cable bolt support systems utilizing instrumentation. Bull. Eng. Geol. Environ. 2000, 58, 227-241. [CrossRef]

38. Liu, J.; Zhao, X.D.; Zhang, S.J.; Xie, L.K. Analysis of support requirements for underground water-sealed oil storagecavern in China. Tunn. Undergr. Space Technol. 2018, 71, 36-46. [CrossRef]

39. Skrzypkowski, K.; Korzeniowski, W.; Zagórski, K.; Dudek, P. Application of Long Expansion Rock Bolt Support in the Underground Mines of Legnica-Głogów Copper District. Studia Geotech. Mech. 2017, 39, 47-57. [CrossRef]

40. Skrzypkowski, K. Evaluation of rock bolt support for Polish hard rock mines. In E3S Web Conference; EDP Sciences: Yulis, France, 2018; p. 01006.

41. Brady, T.; Martin, L.; Pakalnis, R. Empirical approaches for opening design in weak rock masses. Min. Technol. 2005, 114, 13-20. [CrossRef]

42. Lang, T.A.; Bischoff, J.A. Stabilization of rock excavations using rock reinforcement. In The 23rd US Symposium on Rock Mechanics (USRMS); American Rock Mechanics Association: Overland Park, KS, USA, 1982; pp. 935-944.

43. Bieniawski, Z.T. Strata Control in Mineral Engineering; John Wiley \& Sons, Inc.: New York, NY, USA, 1987; pp. 20-43.

44. Wang, K.; Wang, W.Z. Overview of geological characteristics of Hongtoushan copper-zinc deposits, Liaoning Province. Chin. J. Wes. Exp. Eng. 2014, 6, 100-102. (In Chinese)

45. Zhao, X.D. Application of the Kaiser effect of acoustic emission to measure vertical stress in an underground mine. Insight-Non-Destr. Test. Cond. Monit. 2012, 54, 662-666. [CrossRef] 
46. ISRM. Rock Characterization, Testing and Monitoring; Brown, E.T., Ed.; Pergamon Press: Oxford, UK, 1981; p. 211.

47. Bieniawski, Z.T. Geomechanics classification of rock masses and its application in tunneling. In Proceedings of the Third International Congress on Rock Mechanics, Denver, CO, USA, 1-7 September 1974.

48. Laubscher, D.H. A geomechanics classification system for the rating of rock mass in mine design. J. S. Afr. Inst. Min. Metall. 1990, 90, 257-273.

49. Kendorski, F.S.; Cummings, R.A.; Bieniawski, Z.T.; Skinner, E.H. Rock mass classification for block caving mine drift support. In Proceedings of the 5th Congress of the International Society for Rock Mechanics, Melbourne, Australia, 10-15 April 1984.

50. Barton, N.; Lien, R.; Lunde, J. Engineering classification of rock masses for the design of tunnel support. Rock Mech. 1974, 6, 188-236. [CrossRef]

51. Grimstad, E.; Barton, N. Updating the Q-system for NMT. In Proceedings of the International Symposium on Sprayed Concrete-Modern Use of Wet Mix Sprayed Concrete for Underground Support, Fagemes; Norwegian Concrete Association: Oslo, Norway, 1993.

52. Deere, D.U. Technical description of rock cores for engineering purpose. Rock Mech. Rock Eng. 1964, 1, 17-22.

53. Hoek, E.; Kaiser, P.K.; Bawden, W.F. Support of Underground Excavations in Hard Rock; CRC Press: Balkema, Rotterdam, 2000; pp. 31-42.

54. Marinos, P.; Hoek, E. GSI: A geologically friendly tool for rock mass strength estimation. In ISRM International Symposium; International Society for Rock Mechanics and Rock Engineering: Lisbon, Portugal, 2000.

55. Hoek, E.; Carranza-Torres, C.; Corkum, B. Hoek-Brown failure criterion-2002 edition. Proc. NARMS-Tac 2002, 1, 267-273.

56. Basarir, H.; Ozsan, A.; Karakus, M. Analysis of support requirements for a shallow diversion tunnel at Guledar dam site, Turkey. Eng. Geol. 2005, 81, 131-145. [CrossRef]

57. Bieniawski, Z.T. Determining rock mass deformability: Experience from case histories. Int. J. Rock Mech. Min. Sci. 1978, 15, 237-247. [CrossRef]

58. Serafim, J.L.; Pereira, J.P. Considerations of the geomechanics classification of Bieniawski. In Proceedings of the International Symposium on Engineering Geology and Underground Construction LNEC; Balkema: Rotterdam, The Netherlands, 1983.

59. Barton, N.; Loset, F.; Lien, R.; Lunde, J. Application of the Q-System in Design Decisions Concerning Dimensions and Appropriate Support for Underground Installations; Pergamon Press: Pergamon, Turkey, 1980; pp. $23-41$.

60. Nicholson, G.A.; Bieniawski, Z.T. A nonlinear deformation modulus based on rock mass classification. Int. J. Min. Geol. Eng. 1990, 8, 181-202. [CrossRef]

61. Read, S.A.L.; Richards, L.R.; Perrin, N.D. Applicability of the Hoek-Brown failure criterion to New Zealand greywacke rocks. In Proceedings of the 9th International Society for Rock Mechanics Congress, Paris, France, 25-28 January 1999.

62. Ramamurhty, T. Shear strength response of some geological materials in triaxial compression. Int. J. Rock Mech. Min. Sci. 2001, 38, 683-697. [CrossRef]

63. Hoek, E.; Diederichs, M.S. Empirical estimation of rock mass modulus. Int. J. Rock Mech. Min. Sci. 2006, 43, 203-215. [CrossRef]

64. Bhasin, R.; Grimstaad, E. The use of stress-strength relationship in the assessment of tunnel stability. Tunn. Undergr. Space Technol. 1996, 1, 93-98. [CrossRef]

65. Singh, S. Time-Dependent Deformation Modulus of Rocks in Tunnels. Master's Thesis, University of Roorkee, Roorkee, India, 1997.

66. Trueman, R. An Evaluation of Strata Support Techniques in Dual Life Gate Roads. Ph.D. Thesis, University of Wales, Cardiff, UK, 1998.

67. Barton, N. TBM Tunneling in Jointed and Faulted Rock; CRC Press: Rotterdam, Holland, 2000; pp. 53-74.

68. Ramamurthy, T. A geo-engineering classification for rocks and rock masses. Int. J. Rock Mech Min. Sci. 2004, 41, 89-101. [CrossRef]

69. Gurocak, Z.; Solanki, P.; Zaman, M.M. Empirical and numerical analyses of support requirements for a diversion tunnel at the Boztepe dam site, eastern Turkey. Eng. Geol. 2007, 91, 194-208. [CrossRef]

70. Germain, P.; Hadjigeorgiou, J. Influence of stope geometry and blasting patterns on recorded overbreak. Int. J. Rock Mech. Min. Sci. 1997, 34, 3-4. [CrossRef]

71. Milne, D.M. Underground Design and Deformation Based on Surface Geometry. Ph.D. Thesis, The University of British Columbia, Vancouver, BC, Canada, 1997. 
72. Potvin, Y.; Milne, D. Empirical cable bolt support design. In Rock Support in Mining and Underground Construction, Proc. Int. Symp. on Rock Support; Kaiser, P.K., McCreath, D.R., Eds.; Sudbury: Balkema, Rotterdam, 1992.

73. Potvin, Y.; Hudyma, M.; Miller, H.D.S. Design guidelines for open stope support. CIM Bull. 1989, 82, 53-62.

74. Itasca Consulting Group. FLAC3D (Fast Lagrangian Analysis of Continua in 3 Dimensions); Version 5.0; Itasca Consulting Group: Minneapolis, MN, USA, 2013.

75. Rocscience Inc. Underground Wedge Stability Analysis; UNWEDGE Version 3.009; Rocscience Inc.: Toronto, ON, Canada, 2005.

76. Panda, M.K.; Mohanty, S.; Pingua, B.M.P.; Mishra, A.K. Engineering geological and geotechnical investigations along the head race tunnel in Teesta Stage-III hydroelectric project, India. Eng. Geol. 2014, 181, 297-308. [CrossRef]

77. Gurocak, Z. Analyses of stability and support design for a diversion tunnel at the Kapikaya dam site, Turkey. Bull. Eng. Geol. Environ. 2011, 70, 41-52. [CrossRef]

(C) 2019 by the authors. Licensee MDPI, Basel, Switzerland. This article is an open access article distributed under the terms and conditions of the Creative Commons Attribution (CC BY) license (http://creativecommons.org/licenses/by/4.0/). 